\title{
Guidelines on
}

\section{BASIC NEWBORN RESUSCITATION}

Avec résumé d'orientation en Français

Organization 


\title{
WHO Library Cataloguing-in-Publication Data
}

\author{
Guidelines on basic newborn resuscitation.
}

1.Infant, Newborn. 2.Resuscitation - methods. 3.Asphyxia neonatorum - therapy. 4.Guidelines. I.World Health Organization.

\author{
ISBN $9789241503693 \quad$ (NLM classification: WQ 450)
}

\section{(C) World Health Organization 2012}

All rights reserved. Publications of the World Health Organization are available on the WHO web site (www.who.int) or can be purchased from WHO Press, World Health Organization, 20 Avenue Appia, 1211 Geneva 27, Switzerland (tel.: +41 22791 3264; fax: +41 22791 4857; e-mail: bookorders@who.int).

Requests for permission to reproduce or translate WHO publications - whether for sale or for noncommercial distribution - should be addressed to WHO Press through the WHO web site (http://www.who.int/about/licensing/copyright form/en/index.html).

The designations employed and the presentation of the material in this publication do not imply the expression of any opinion whatsoever on the part of the World Health Organization concerning the legal status of any country, territory, city or area or of its authorities, or concerning the delimitation of its frontiers or boundaries. Dotted lines on maps represent approximate border lines for which there may not yet be full agreement.

The mention of specific companies or of certain manufacturers' products does not imply that they are endorsed or recommended by the World Health Organization in preference to others of a similar nature that are not mentioned. Errors and omissions excepted, the names of proprietary products are distinguished by initial capital letters.

All reasonable precautions have been taken by the World Health Organization to verify the information contained in this publication. However, the published material is being distributed without warranty of any kind, either expressed or implied. The responsibility for the interpretation and use of the material lies with the reader. In no event shall the World Health Organization be liable for damages arising from its use.

Printed in (country name) 


\section{CONTENTS}

$\begin{array}{ll}\text { ACKNOWLEDGMENTS } & 4\end{array}$

$\begin{array}{ll}\text { ACRONYMS } & 5\end{array}$

$\begin{array}{ll}\text { EXECUTIVE SUMMARY } & 6\end{array}$

RESUME D'ORIENTATION

$\begin{array}{ll}\text { INTRODUCTION AND SCOPE } & 15\end{array}$

$\begin{array}{ll}\text { METHODOLOGY } & 18\end{array}$

$\begin{array}{ll}\text { RECOMMENDATIONS } & \mathbf{2 1}\end{array}$

$\begin{array}{ll}\text { RESEARCH PRIORITIES } & 44\end{array}$

IMPLEMENTATION AND EVALUATION

$\begin{array}{ll}\text { References } & \mathbf{5 0}\end{array}$

$\begin{array}{ll}\text { Annex 1: GRADE profile summaries } & 56\end{array}$

Annex 2: List of external participants 
The Department for Maternal, Newborn, Child and Adolescent Health of the World Health Organization gratefully acknowledges the contributions that many individuals and organizations made to the development of these guidelines.

José Luis Díaz-Rossello, Peter Gisore, Susan Niermeyer, Vinod K Paul, Ana Quiroga, Ola Didrik Saugstad, Maria Asunción Silvestre, Nalini Singhal, Takahiro Sugiura and Fabio Uxa served as members of the Guidelines Development Group which developed the recommendations.

Uwe Ewald, Pavitra Mohan, Yana Richens, Frederik Were and David Woods contributed to the development of PICO questions and/or provided peer review.

WHO staff members involved included: Rajiv Bahl, José Martines, Matthews Mathai, Mario Merialdi, Metin Gülmezoglu, Severin von Xylander and Jelka Zupan. Mari Jeevasankar of the All India Institute of Medical Sciences, WHO Collaborating Centre on Newborn Care, assisted in compiling, synthesizing and evaluating the evidence underlying each recommendation. Karen Mulweye provided secretarial support. The guidelines document was edited by Peggy Henderson.

The International Liaison Committee on Resuscitation coordinated their evidence review process with this one and shared information in a spirit of open collaboration.

Various organizations were represented in the process by observers who provided valuable comments. These included: Vincent Faveau and Yaron Wolman (United Nations Population Fund), Patricia Gomez (Jhpiego), Lily Kak (United States Agency for International Development) and William J Keenan (American Academy of Pediatrics and International Pediatric Association).

The United States Agency for International Development provided financial support, without which this work could not have been completed. 
CI

ES

GDG

GRADE

HIE

HQ

ILCOR

MAS

MCA

MD

NGO

NICU

NMR

PICO

PPV

RCT

$\mathrm{RR}$

Sp02

UNFPA

UNICEF

USAID
Confidence interval

Effect size

Guidelines Development Group

The system for grading the quality of evidence and the strength of recommendations

Hypoxic ischaemic encephalopathy

Headquarters

International Liaison Committee on Resuscitation

Meconium aspiration syndrome

Department of Maternal, Newborn, Child and Adolescent Health

Mean difference

Nongovernmental organization

Neonatal intensive care unit

Neonatal mortality rate

Population/Patient group, Intervention, Comparator and Outcome

Positive-pressure ventilation

Randomized controlled trial

Relative risk

Oxygen saturation

United Nations Population Fund

United Nations Children's Fund

United States Agency for International Development 
Globally, about one quarter of all neonatal deaths are caused by birth asphyxia. In this document, birth asphyxia is defined simply as the failure to initiate and sustain breathing at birth. Effective resuscitation at birth can prevent a large proportion of these deaths. The need for clinical guidelines on basic newborn resuscitation, suitable for settings with limited resources, is universally recognized. WHO had responded to this need by developing guidelines for this purpose that are contained in the document Basic newborn resuscitation: a practical guide. As this document is over a decade old, a process to update the guidelines on basic newborn resuscitation was initiated in 2009.

The International Liaison Committee on Resuscitation (ILCOR) published Consensus on science and treatment recommendations for neonatal resuscitation in 2000, 2005 and 2010. Regional resuscitation councils publish guidelines based on the ILCOR consensus; however, these generally are not designed for resource-limited settings, and require the presence of more than one health provider with extensive training as well as advanced technology. The objective of these updated WHO guidelines is to ensure that newborns in resource-limited settings who require resuscitation are effectively resuscitated. These guidelines will inform WHO training and reference materials, such as Pregnancy, childbirth, postpartum and newborn care: a guide for essential practice; Essential newborn care course; Managing newborn problems: a guide for doctors, nurses and midwives; and Pocket book of hospital care for children: guidelines for the management of common illnesses with limited resources. These guidelines will assist programme managers responsible for implementing maternal and child health programmes to develop or adapt national or local guidelines, standards and training materials on newborn care.

The Guideline Development Group considered evidence related to the 13 highest-priority research questions for development of recommendations. For each question, mortality and severe morbidity were considered to be critical outcomes. Benefits and harms in critical outcomes formed the basis of the recommendations for each question. Studies from lowand middle- income as well as high-income countries were considered for inclusion in evidence reviews. Studies that did not address any of the pre-defined outcomes, were unpublished or were available only as an abstract were excluded. Animal studies were included only when sufficient evidence from human studies was not available. Efforts were made to identify relevant English and non-English language articles. A standardized form was used to extract relevant information from studies. Systematically extracted data included: study identifiers, setting, design, participants, sample size, intervention or exposure, control or comparison group, outcome measures and results. Quality characteristics were also recorded for all studies: allocation concealment or risk of selection bias (observational studies); blinding of intervention or observers, or risk of measurement bias; loss to follow-up; intention to treat analysis or adjustment for confounding factors; and analysis adjusted for cluster randomization (the latter only for cluster-randomized controlled trials). The GRADE approach was used for assessing the quality of evidence and the recommendations (for details, see Methodology section). For each set of studies reporting results for a given outcome, the quality of studies was graded as high, moderate, low or very low.

The strength of a recommendation reflects the degree of confidence that the desirable effects of adherence to a recommendation outweigh the undesirable effects. Decisions on these issues were made by the Guidelines Development Group, which met in June 2011, on 
the basis of evidence of benefits and harms; quality of evidence; values and preferences of policy-makers, health care providers and parents; and whether costs are qualitatively justifiable relative to benefits in low- and middle- income countries. Each recommendation was graded as strong when there was confidence that the benefits clearly outweigh the harms, or weak when the benefits probably outweigh the harms, but there was uncertainty about the trade-offs. The resulting recommendations are shown below.

\section{WHO Recommendations on Basic Newborn Resuscitation}

\begin{tabular}{|c|c|c|c|}
\hline No. & Recommendation ${ }^{*}$ & $\begin{array}{l}\text { Strength of } \\
\text { recommendation }\end{array}$ & Quality of evidence \\
\hline & IMMEDIATE CARE AFTER BIRTH & & \\
\hline 1. & $\begin{array}{l}\text { In newly-born term or preterm babies who do not } \\
\text { require positive-pressure ventilation, the cord should } \\
\text { not be clamped earlier than one minute after birth }{ }^{1} \text {. } \\
\text { When newly-born term or preterm babies require } \\
\text { positive-pressure ventilation, the cord should be } \\
\text { clamped and cut to allow effective ventilation to be } \\
\text { performed. }\end{array}$ & $\begin{array}{l}\text { Strong } \\
\text { Weak }\end{array}$ & $\begin{array}{l}\text { High to moderate } \\
\text { Guidelines Development Group } \\
\text { (GDG) consensus in absence of } \\
\text { published evidence }\end{array}$ \\
\hline 2. & $\begin{array}{l}\text { Newly-born babies who do not breathe spontaneously } \\
\text { after thorough drying should be stimulated by rubbing } \\
\text { the back } 2-3 \text { times before clamping the cord and } \\
\text { initiating positive-pressure ventilation. }\end{array}$ & Weak & $\begin{array}{l}\text { GDG consensus in absence of } \\
\text { published evidence }\end{array}$ \\
\hline 3. & $\begin{array}{l}\text { In neonates born through clear amniotic fluid who } \\
\text { start breathing on their own after birth, suctioning of } \\
\text { the mouth and nose should not be performed. } \\
\text { In neonates born through clear amniotic fluid who do } \\
\text { not start breathing after thorough drying and rubbing } \\
\text { the back 2-3 times, suctioning of the mouth and nose } \\
\text { should not be done routinely before initiating positive- } \\
\text { pressure ventilation. Suctioning should be done only if } \\
\text { the mouth or nose is full of secretions. }\end{array}$ & Weak & $\begin{array}{l}\text { GDG consensus in absence of } \\
\text { published evidence }\end{array}$ \\
\hline 4. & $\begin{array}{l}\text { In the presence of meconium-stained amniotic fluid, } \\
\text { intrapartum suctioning of the mouth and nose at the } \\
\text { delivery of the head is not recommended. }\end{array}$ & Strong & Low \\
\hline 5. & $\begin{array}{l}\text { In neonates born through meconium-stained amniotic } \\
\text { fluid who start breathing on their own, tracheal } \\
\text { suctioning should not be performed. } \\
\text { In neonates born through meconium-stained amniotic }\end{array}$ & Weak & $\begin{array}{l}\text { Moderate to low } \\
\text { GDG consensus in absence of }\end{array}$ \\
\hline
\end{tabular}

\footnotetext{
1 "Not earlier than one minute" should be understood as the lower limit supported by published evidence. WHO Recommendations for the prevention of postpartum haemorrhage (Fawole B et al. Geneva, WHO, 2007) state that the cord should not be clamped earlier than is necessary for applying cord traction, which the GDG clarified would normally take around 3 minutes.
} 


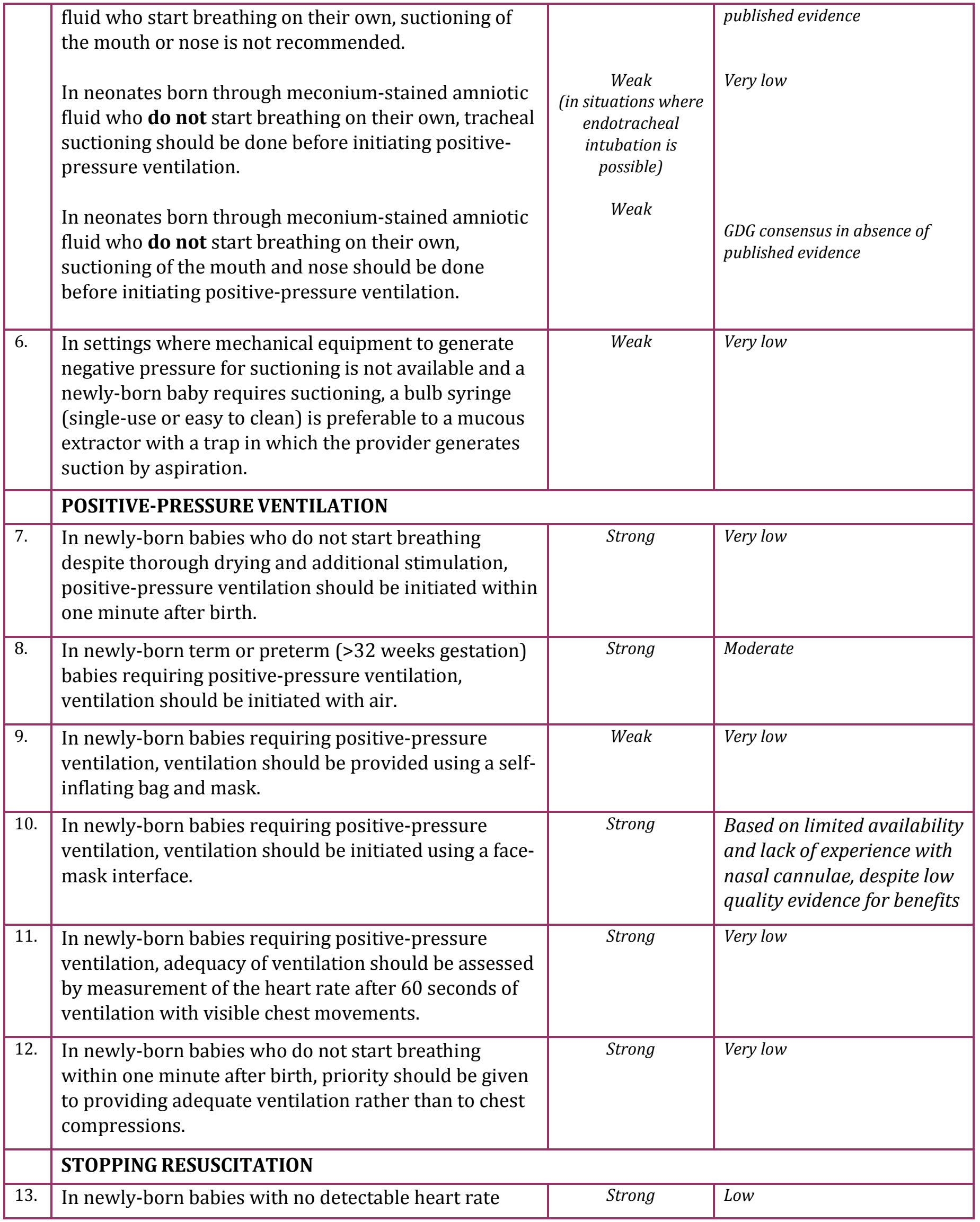




\begin{tabular}{|l|l|c|}
\hline $\begin{array}{l}\text { after } 10 \text { minutes of effective ventilation, resuscitation } \\
\text { should be stopped. }\end{array}$ & $\begin{array}{c}\text { Weak } \\
\text { (relevant to } \\
\text { resource-limited } \\
\text { settings) }\end{array}$ & Very low \\
$\begin{array}{l}\text { In newly-born babies who continue to have a heart } \\
\text { after } 20 \text { minutes of resuscitation, resuscitation should } \\
\text { be stopped. }\end{array}$ & \\
\hline
\end{tabular}


Environ un quart de l'ensemble des décès néonatals dans le monde sont causés par une hypoxie à la naissance. Dans ce document, une hypoxie à la naissance est définie simplement comme l'incapacité de commencer à respirer à la naissance et de continuer à le faire de manière pérenne. Une proportion importante de ces décès peuvent être prévenus par une réanimation efficace à la naissance. Disposer de directrices cliniques sur les premiers soins de réanimation du nouveau-né adaptées aux situations de ressources limitées est un besoin universellement reconnu. Pour y répondre, l'OMS a élaboré des lignes directrices qui se trouvent dans le document Premiers soins de réanimation du nouveau-né : guide pratique. Ce document datant de plus de dix ans, un processus a été mis en route en 2009 pour mettre à jour ces lignes directrices.

L'International Liaison Committee on Resuscitation (ILCOR) a publié en 2000, 2005 et 2010 un document intitulé Consensus on science and treatment recommendations for neonatal resuscitation (Consensus sur les données scientifiques et les recommandations en matière de traitement pour la réanimation néonatale). Des conseils régionaux sur la réanimation publient des lignes directrices en s'appuyant sur ce consensus ILCOR. Cependant, ces lignes directrices ne sont généralement pas conçues pour les situations de ressources limitées et exigent la présence de plus d'un agent de santé formé de manière approfondie et de technologies avancées. L'objectif des lignes directrices actualisées de l'OMS décrites dans le présent document est de s'assurer qu'en situation de ressources limitées, les nouveau-nés qui ont besoin d'une réanimation bénéficient d'une réanimation efficace. Ces lignes directrices serviront de base aux matériels de formation et de référence de l'OMS, notamment aux documents suivants : Soins liés à la grossesse, à l'accouchement et à la période néonatale : guide de pratiques essentielles; Essential newborn care course (Cours de formation sur les soins essentiels du nouveau-né); Prise en charge des problèmes du nouveau-né: manuel de la sage-femme, de l'infirmière et du médecin; et Soins hospitaliers pédiatriques: prise en charge des affections courantes dans les petits hôpitaux. Elles aideront les administrateurs de programme responsables de l'exécution des programmes de santé maternelle et infantile à élaborer ou à adapter des directives, des normes et des matériels de formation à usage national ou local sur les soins du nouveau-né.

Afin d'élaborer des recommandations, le Groupe d'élaboration des lignes directrices a pris en considération les données relatives aux 13 questions de recherche présentant le plus haut niveau de priorité. Pour chaque question, la mortalité et la morbidité sévère ont été considérées comme des résultats essentiels. Pour chacune des questions, les recommandations ont été basées sur les avantages et les dangers pour les résultats essentiels. Les études menées dans les pays à revenu faible ou moyen et dans les pays à revenu élevé ont été prises en considération pour faire partie de l'examen des données. Les études ne traitant pas des résultats prédéfinis, n'ayant pas fait l'objet d'une publication ou uniquement disponibles sous la forme d'un résumé ont été exclues. Les études menées chez l'animal n'ont été retenues que si l'on ne disposait pas de données suffisantes issues d'études menées chez l'homme. Des mesures ont été prises afin d'identifier les articles pertinents publiés en langue anglaise ou dans une autre langue. Un formulaire normalisé a été utilisé pour extraire des études les informations pertinentes. Les données obtenues de manière systématique étaient les suivantes : identificateur de l'étude, cadre, méthodologie, participants, taille de l'échantillon, intervention ou exposition, groupe témoin ou groupe de comparaison, critères de jugement et résultats. Des caractéristiques relatives à la qualité ont également été enregistrées pour chaque étude: dissimulation de l'affectation des sujets aux groupes d'étude ou risque de biais de sélection (études observationnelles) ; mesures pour garantir l'intervention en aveugle ou le travail des observateurs en aveugle ou risque de biais de mesure ; perdus de vue ; analyse selon l'intention de traiter ou ajustement pour tenir compte des facteurs de confusion; et analyse avec ajustement pour tenir compte de la randomisation en grappe (cette caractéristique ne s'appliquant qu'aux essais contrôlés randomisés en grappes). L'approche GRADE a été utilisée pour évaluer la qualité des données et des recommandations (des informations supplémentaires se trouvent dans la section Méthodologie). Pour 
chaque ensemble d'études disposant de résultats pour un critère de jugement donné, un grade a été attribué à la qualité des études (qualité bonne, moyenne, faible ou très faible).

La force d'une recommandation représente le degré de confiance avec lequel les effets souhaités obtenus en suivant cette recommandation l'emportent sur les effets indésirables. Le Groupe d'élaboration des lignes directrices a tranché sur ces questions lors d'une réunion qui s'est tenue en juin 2011. Les décisions ont été prises en se fondant sur les éléments suivants : données relatives aux avantages et aux dangers ; qualité des données ; valeurs et préférences accordées par les responsables de l'élaboration des politiques, les agents de santé et les parents ; et si les coûts étaient justifiés sur le plan qualitatif par rapport aux avantages dans les pays à revenu faible ou moyen. Chaque recommandation a été classée comme étant forte s'il pouvait être affirmé avec confiance que les avantages l'emportaient clairement sur les dangers ou comme étant faible lorsque les avantages l'emportaient probablement sur les dangers, mais que l'équilibre ne pouvait pas être déterminé avec certitude. Les recommandations qui en découlent sont présentées cidessous.

\section{Recommandations 2012 de l'OMS sur les premiers soins de réanimation du nouveau-né}

\section{No} Recommandation

Force de la

recommandation

Qualité des données

SOINS IMMÉDIATS APRÈS LA NAISSANCE

1. Chez un nouveau-né à terme ou prématuré qui ne nécessite pas de ventilation en pression positive à la naissance, le cordon doit être clampé au plus tôt une minute après la naissance. ${ }^{1}$

Si un nouveau-né à terme ou prématuré nécessite une ventilation en pression positive à la naissance, le cordon doit être clampé et coupé pour permettre d'effectuer une ventilation efficace.

2. Un nouveau-né qui ne respire pas spontanément à la naissance après avoir été essuyé doit être stimulé en lui frottant le dos à deux ou trois reprises avant de clamper le cordon et de commencer une ventilation en pression positive.

3. $\quad$ Chez un nouveau-né pour qui le liquide amniotique était clair et qui commence à respirer spontanément après la naissance, il ne faut pas effectuer d'aspiration de la bouche et du nez.

Chez un nouveau-né pour qui le liquide amniotique était clair et qui ne commence pas à respirer après avoir été essuyé entièrement et stimulé en lui frottant le dos à deux ou trois reprises, une aspiration de la bouche et du nez ne doit pas être effectuée de manière systématique avant de commencer une ventilation en pression positive. Une aspiration ne doit être effectuée que si le nez ou la bouche est rempli de sécrétions.

\footnotetext{
${ }^{1}$ "Au plus tôt une minute » doit être considéré comme la limite inférieure sur la base des données publiées. Dans le document WHO Recommendations for the prevention of postpartum haemorrhage (Fawole B et al. Genève, OMS, 2007), il est stipulé que le cordon ne doit pas être clampé plus tôt que nécessaire pour réaliser une traction du cordon; le Groupe d'élaboration des lignes directrices a précisé que cela prend habituellement environ trois minutes.
} 


\begin{tabular}{|c|c|c|c|}
\hline 4. & $\begin{array}{l}\text { En présence de liquide amniotique teinté de méconium, il } \\
\text { n'est pas recommandé d'effectuer une aspiration per- } \\
\text { partum de la bouche et du nez après accouchement de la } \\
\text { tête. }\end{array}$ & Forte & Faible \\
\hline \multirow[t]{4}{*}{5.} & $\begin{array}{l}\text { Chez un nouveau-né pour qui le liquide amniotique était } \\
\text { teinté de méconium et qui commence à respirer par lui- } \\
\text { même, il ne faut pas effectuer d'aspiration trachéale. }\end{array}$ & Forte & Moyenne à faible \\
\hline & $\begin{array}{l}\text { Chez un nouveau-né pour qui le liquide amniotique était } \\
\text { teinté de méconium et qui commence à respirer par lui- } \\
\text { même, il n'est pas recommandé d'effectuer une aspiration } \\
\text { de la bouche et du nez. }\end{array}$ & Faible & $\begin{array}{l}\text { Consensus du Groupe } \\
\text { d'élaboration des lignes } \\
\text { directrices, en l'absence de } \\
\text { données publiées }\end{array}$ \\
\hline & $\begin{array}{l}\text { Chez un nouveau-né pour qui le liquide amniotique était } \\
\text { teinté de méconium et qui ne commence pas à respirer } \\
\text { par lui-même, une aspiration trachéale doit être effectuée } \\
\text { avant de commencer une ventilation en pression positive. }\end{array}$ & $\begin{array}{l}\text { Faible } \\
\text { (dans les } \\
\text { situations où une } \\
\text { intubation } \\
\text { endotrachéale est } \\
\text { possible) }\end{array}$ & Très faible \\
\hline & $\begin{array}{l}\text { Chez un nouveau-né pour qui le liquide amniotique était } \\
\text { teinté de méconium et qui ne commence pas à respirer } \\
\text { spontanément, une aspiration de la bouche et du nez doit } \\
\text { être effectuée avant de commencer une ventilation en } \\
\text { pression positive. }\end{array}$ & Faible & $\begin{array}{l}\text { Consensus du Groupe } \\
\text { d'élaboration des lignes } \\
\text { directrices, en l'absence de } \\
\text { données publiées }\end{array}$ \\
\hline \multirow[t]{2}{*}{6.} & $\begin{array}{l}\text { Dans les situations où aucun dispositif mécanique pour } \\
\text { obtenir la pression négative nécessaire pour effectuer une } \\
\text { aspiration n'est disponible et qu'un nouveau-né a besoin } \\
\text { d'une aspiration à la naissance, il est préférable d'utiliser } \\
\text { une poire (à usage unique ou facile à nettoyer) à un } \\
\text { extracteur de mucosités avec réservoir pour lequel } \\
\text { l'aspiration est produite par l'agent de santé. }\end{array}$ & Faible & Très faible \\
\hline & \multicolumn{3}{|l|}{ VENTILATION EN PRESSION POSITIVE } \\
\hline 7. & $\begin{array}{l}\text { Chez un nouveau-né qui ne commence pas à respirer à la } \\
\text { naissance après avoir été essuyé entièrement et avoir reçu } \\
\text { des stimulations supplémentaires, une ventilation en } \\
\text { pression positive doit être commencée dans la minute qui } \\
\text { suit la naissance. }\end{array}$ & Forte & Très faible \\
\hline 8. & $\begin{array}{l}\text { Chez un nouveau-né à terme ou prématuré ( }>32 \text { semaines } \\
\text { de gestation) qui nécessite une ventilation en pression } \\
\text { positive à la naissance, la ventilation doit être commencée } \\
\text { en utilisant de l'air. }\end{array}$ & Forte & Moyenne \\
\hline 9. & $\begin{array}{l}\text { Chez un nouveau-né qui nécessite une ventilation en } \\
\text { pression positive à la naissance, la ventilation doit être } \\
\text { effectuée en utilisant un insufflateur manuel et un } \\
\text { masque. }\end{array}$ & Faible & Très faible \\
\hline 10. & $\begin{array}{l}\text { Chez un nouveau-né qui nécessite une ventilation en } \\
\text { pression positive à la naissance, la ventilation doit être } \\
\text { commencée en utilisant pour interface un masque. }\end{array}$ & Forte & $\begin{array}{l}\text { Fondée sur la disponibilité } \\
\text { réduite de la canule nasale et } \\
\text { le manque d'expérience dans } \\
\text { son utilisation, malgré } \\
\text { l'existence de données de } \\
\text { faible qualité sur ses } \\
\text { avantages }\end{array}$ \\
\hline
\end{tabular}




\begin{tabular}{|l|l|c|l|}
\hline 11. & $\begin{array}{l}\text { Chez un nouveau-né qui nécessite une ventilation en } \\
\text { pression positive à la naissance, l'efficacité de la } \\
\text { ventilation doit être évaluée en mesurant la fréquence } \\
\text { cardiaque après 6o secondes de ventilation avec des } \\
\text { mouvements thoraciques visibles. }\end{array}$ & Très faible \\
\hline 12. & $\begin{array}{l}\text { Chez un nouveau-né qui ne commence pas à respirer dans } \\
\text { la minute qui suit la naissance, il faut effectuer en priorité } \\
\text { une ventilation adéquate plutôt que des compressions } \\
\text { thoraciques. }\end{array}$ & Forte & Très faible \\
\hline 13. & $\begin{array}{l}\text { ARRÊT DE LA RÉANIMATION } \\
\text { Chez un nouveau-né à la naissance pour qui aucun } \\
\text { vattement cardiaque n'est détectable après 10 minutes de } \\
\text { ventilation efficace, la réanimation doit être arrêtée. } \\
\text { Chez un nouveau-né à la naissance qui continue d'avoir un } \\
\text { rythme cardiaque inférieur à 6o battements par minute et } \\
\text { qui ne présente aucune respiration spontanée après } \\
\text { 20 minutes de réanimation, la réanimation doit être } \\
\text { arrêtée. }\end{array}$ & $\begin{array}{l}\mid \text { Forte } \\
\text { (pertinente pour } \\
\text { les situations de } \\
\text { ressources } \\
\text { limitées) }\end{array}$ & Faible \\
\hline
\end{tabular}




\section{INTRODUCTION AND SCOPE}

About one quarter of all neonatal deaths globally are caused by birth asphyxia ${ }^{1}$. In this document, birth asphyxia is defined simply as the failure to initiate and sustain breathing at birth. Effective resuscitation at birth can prevent a large proportion of these deaths. The need for clinical guidelines on basic newborn resuscitation, suitable for settings with limited resources, is universally recognized. WHO had responded to this need by developing guidelines for this purpose that are contained in the document Basic newborn resuscitation: a practical guide ${ }^{2}$. As this document is over a decade old, a process to update the guidelines on basic newborn resuscitation was initiated in 2009.

The International Liaison Committee on Resuscitation (ILCOR) published Consensus on science and treatment recommendations for neonatal resuscitation in $2000^{3}, 2005^{4}$ and $2010^{5}$. Regional resuscitation councils publish guidelines based on the ILCOR consensus; however, these guidelines generally are not designed for resource-limited settings, and require the presence of more than one health care provider with extensive training, as well as advanced technology.

The objective of these WHO guidelines is to ensure that newborns in resource-limited settings who require resuscitation are effectively resuscitated. These guidelines will inform WHO training and reference materials such as Pregnancy, childbirth, postpartum and newborn care: a guide for essential practice ${ }^{6}$; Essential newborn care course ${ }^{7}$; Managing newborn problems: a guide for doctors, nurses and midwives ${ }^{8}$; and Pocket book of hospital care for children: guidelines for the management of common illnesses with limited resources ${ }^{9}$. These guidelines will assist programme managers responsible for implementing maternal and child health programmes to develop or adapt national or local guidelines, standards and training materials on newborn care.

\section{Target audience}

${ }^{1}$ About $40 \%$ of all under five deaths occurred in the neonatal period in 2008; in the same period asphyxia was the cause of $9 \%$ of all under five deaths (WHO. World health statistics. Geneva, WHO, 2011).

${ }^{2}$ WHO. Basic newborn resuscitation: a practical guide. Geneva, WHO, 1998.

32000 Guidelines for cardiopulmonary resuscitation and emergency cardiovascular care: international consensus on science, Part 11: Neonatal resuscitation. Circulation, 2000, 102(Suppl. 1):1343-1358.

${ }^{4} 2005$ International consensus on cardiopulmonary resuscitation and emergency cardiovascular care science with treatment recommendations. Part 7: Neonatal resuscitation. Circulation, 2005, 112:III-91-III-99.

${ }^{5} 2010$ International consensus on cardiopulmonary resuscitation and emergency cardiovascular care science with treatment recommendations. Part 11: Neonatal resuscitation: Circulation, 2010, 122(Suppl. 2):S516 -S538.

${ }^{6} \mathrm{WHO}$ et al. Pregnancy, childbirth, postpartum and newborn care: a guide for essential practice. Geneva, WHO, 2006;

${ }^{7}$ WHO. Essential newborn care course. Geneva, WHO, 2010.

${ }^{8}$ WHO. Managing newborn problems: a guide for doctors, nurses and midwives. Geneva, WHO, 2003.

${ }^{9}$ WHO. Pocket book of hospital care for children: guidelines for the management of common illnesses with limited resources. Geneva, WHO, 2005. 
The primary audience for these guidelines is health professionals who are responsible for attending women in childbirth or for care of the newborn baby immediately after birth, primarily in areas where resources are limited. These health professionals include skilled birth attendants, typically but not limited to midwives, nurse-midwives and auxiliary nursemidwives who conduct births in primary health care facilities and at home. However, the guidelines are also expected to be used by policy-makers and managers of maternal and child health programmes, health facilities and teaching institutions to set up and maintain maternity and newborn care services. The information in these guidelines will be included in job aids and tools for both pre- and in-service training of health professionals and to improve their knowledge, skills and performance in basic newborn resuscitation.

\section{Population of interest}

The guidelines focus on basic resuscitation of newborns born in resource-limited settings in low- and middle-income countries, often with a single skilled birth attendant.

\section{Critical outcomes}

The two critical outcomes were mortality and severe morbidity (including hypoxic ischaemic encephalopathy [HIE], meconium aspiration syndrome [MAS], pulmonary air leaks including pneumothorax, intraventricular haemorrhage, severe anaemia, admission to neonatal intensive care unit, severe hyperbilirubinaemia and cerebral palsy). Other important outcomes considered included Apgar scores, onset of spontaneous respiration, need for chest compressions, need for endotracheal intubation, oxygen saturation and duration of hospital stay.

\section{Priority questions}

A total of 13 PICO$^{1}$ questions were formulated at a technical consultation on neonatal resuscitation in 2009 for evidence collation and synthesis. This consultation was jointly organized by the Department of Child and Adolescent Health and the Department of Making Pregnancy Safer. The two Departments were subsequently merged to form the Department of Maternal, Newborn, Child and Adolescent Health (MCA). The questions were:

1. In normal or depressed ${ }^{2}$ newly-born babies (P), does late cord clamping (I) compared with standard management $(\mathrm{C})$ improve outcome $(\mathrm{O})$ ?

2. In neonates not breathing spontaneously after birth (P), does additional stimulation (I) compared with thorough drying alone (C) reduce the need for positive-pressure ventilation (PPV) (O)?

3. In depressed neonates with clear amniotic fluid (P), does suctioning of the mouth and nose (I) before starting PPV versus no suctioning (C) improve outcome (O)?

4. In neonates born through meconium-stained amniotic fluid (P), does intrapartum oropharyngeal and nasopharyngeal suctioning at the delivery of the head (I) compared with no intrapartum suctioning (C) prevent MAS and mortality (0)?

\footnotetext{
${ }^{1}$ PICO: Population/Patient Group, Intervention, Comparator, and Outcome. A PICO question is one that is formulated using the PICO framework, wherein the health care providers ask and answer a series of questions meant to elicit information about their patients and their conditions, interventions that have been undertaken or should be taken, any comparisons between the current treatment and possible alternatives, and outcomes to be desired or achieved.

${ }^{2} \mathrm{~A}$ "depressed" newborn is a baby not breathing or crying at birth who usually has poor muscle tone and heart rate below 100 beats/minute.
} 
5. In neonates born through meconium-stained amniotic fluid (P), does oropharyngeal and/or endotracheal suction (I) compared with no suctioning of either oropharynx or trachea (C) prevent MAS and mortality (O)?

6. In neonates who require suction to clear their airways $(\mathrm{P})$, what is the safety and efficacy (O) of different types of suction devices (I/C)?

7. In neonates who fail to breathe after birth (P), should PPV be initiated within one minute after birth if the baby has not started breathing after initial steps of resuscitation (I) as compared to a later time (C) for preventing HIE and mortality $(0)$ ?

8. In newborns who require resuscitation at birth (P), is PPV with air (I) more effective than that with higher concentrations of oxygen (C) in reducing subsequent mortality and HIE (0)?

9. In neonates who require PPV (P), does ventilation with a self-inflating bag and mask (I) compared with mouth-to-tube and mask (or mouth-to-mask) ventilation (C) improve outcome (0)?

10. In neonates receiving PPV (P), does the use of nasal cannulae (I) versus face-mask interface $(\mathrm{C})$ improve outcome $(\mathrm{O})$ ?

11. In neonates who require PPV (P), is measuring heart rate and chest movements (I) compared with chest movements alone (C) better to assess ventilation (O)?

12. In neonates requiring resuscitation after birth (P), is PPV alone (I) as effective as PPV and chest compressions $(\mathrm{C})$ in reducing mortality $(\mathrm{O})$ ?

13. In neonates who continue to have no heart rate or severe bradycardia despite resuscitation (P), should resuscitation efforts be stopped after 10 minutes (I) as opposed to $\mathbf{2 0}$ minutes or longer $(\mathrm{C})$ ?

Additionally, the consultation identified the following two questions: "What maternal history factors predict need for newborn resuscitation at birth?" and "What are ethicallyjustified reasons for not initiating resuscitation in newly-born infants affected by conditions associated with high mortality and morbidity?" The former question could not be addressed because of the time required in the systematic review on this complex question. In addition, the Guideline Development Group (GDG) at its June 2011 meeting agreed that the question was not critical. A birth attendant needs to be prepared for newborn resuscitation at every birth in any case, as a substantial proportion of newborns who need resuscitation do not have any maternal risk factor. For ethically-justified reasons for not initiating resuscitation, the GDG felt that this situation was very context-specific, so that making a general recommendation would not be appropriate. 


\section{Guideline Development Group}

The GDG that developed the recommendations and decided on their strength was constituted by the following external experts: Peter Gisore (African Region); Jose Luis DíazRossello, Susan Niermeyer, Ana Quiroga and Nalini Singhal (Region of the Americas); Vinod $\mathrm{K}$ Paul (South-East Asia Region, participated in the GDG meeting by telephone and email); Ola Didrik Saugstad and Fabio Uxa (European Region); María Asunción Silvestre and Takahiro Sugiura (Western Pacific Region).

All GDG members completed a WHO Declaration of Interest form. Out of the ten members, four declared a potential conflict of interest in the subject matter of the meeting, as follows:

1. Susan Niermeyer was the consulting editor for the publication of the American Academy of Pediatrics, Helping Babies Breathe, from 2008-2011 and received a significant remuneration for this consultancy. She is an author of worksheets used for the 2000, 2005 and 2010 International Consensus on Cardiopulmonary Resuscitation and Emergency Cardiovascular Care Science with Treatment Recommendations of ILCOR.

2. Ola Didrik Saugstad has applied for a patent on metabolic markers for birth asphyxia, applicable in well-resourced settings (not for basic newborn resuscitation) and has received significant grants from public funds (Norwegian Research Council and Oslo University Hospital) and a private company (Laerdal) for research on birth asphyxia. He has not received any personal remuneration for any of the above.

3. Nalini Singhal is the author of worksheets for the 2010 International Consensus on Cardiopulmonary Resuscitation and Emergency Cardiovascular Care Science with Treatment Recommendations of ILCOR, serves on the editorial board for the publication of the American Academy of Pediatrics, Helping Babies Breathe, and leads the educational evaluation of that training course. She has not received any remuneration for this work.

4. Vinod K Paul has provided technical advice related to the topic of the meeting to the Government of India and academic bodies. He has not received any remuneration for this work.

These largely professional declarations of interest were considered by the WHO Steering Group, who found that they did not pose a major risk of bias in recommendations. None of the above experts were therefore precluded from participation in the GDG meeting to formulate recommendations.

The WHO Steering Group consisted of the following staff members: Maternal, Newborn, Child and Adolescent Health (MCA)1: Rajiv Bahl, José Martines, Matthews Mathai, Severin von Xylander and Jelka Zupan; Reproductive Health and Research: Metin Gulmezoglu and Mario Merialdi.

\footnotetext{
${ }^{1}$ The Departments of Child and Adolescent Health and Development (CAH) and Making Pregnancy Safer (MPS) were merged in 2010 as the Department for Maternal, Newborn, Child and Adolescent Health.
} 
The following external experts reviewed the research questions and/or draft guidelines: Uwe Ewald, Pavitra Mohan, Yana Richens, Frederik Were and David Woods.

Throughout 2010, MCA coordinated efforts to review and synthesize the evidence on the identified priority questions. The availability of reviews related to many of the identified questions conducted by ILCOR was helpful. ${ }^{1}$ The WHO process included targeted, systematic reviews of relevant literature, preparation of GRADE 2 profiles, and analysis of the risk-benefits, values and preferences, and costs of implementation.

A literature search of the Cochrane Database and OVID-Medline was conducted in July 2010 to identify high quality, systematic reviews from the previous two years that were relevant to the priority PICO questions. Where data were not available or up-to-date from the two sources, systematic reviews were commissioned to various groups to collate the evidence.

The systematic reviews, meta-analyses and GRADE profiles followed the methodology recommended by the Guidelines Review Committee. Where data were lacking, systematic searches were conducted from various electronic databases, including Medline/PubMed, Embase, CENTRAL, NLM Gateway and WHO regional databases. Applicable ILCOR research strategies were updated with literature available through April 2011.

Studies from low- and middle-income as well as high- income countries were considered for inclusion in evidence reviews. Efforts were made to identify relevant English and nonEnglish language articles. A standardized form was used to extract relevant information from studies. Systematically extracted data included: study identifiers, setting, design, participants, sample size, intervention or exposure, control or comparison group, outcome measures and results. Quality characteristics also were recorded for all studies: allocation concealment or risk of selection bias (observational studies); blinding of intervention or observers, or risk of measurement bias; loss to follow-up; and intention to treat analysis or adjustment for confounding factors. For each question, data on critical and secondary outcomes were extracted and appraised by evaluating the quality, consistency, and external validity of the evidence.

\section{Grading the quality of evidence}

An adapted GRADE approach for assessing and grading the quality of evidence was used. Quality was defined as the extent to which one could be confident that an estimate of effect or association was correct.The quality of the set of included studies reporting results for an outcome was graded as high, moderate, low or very low. The implications of these categories are detailed in Table 1.

1 ILCOR. Special Report -Neonatal resuscitation: 2010 international consensus on cardiopulmonary resuscitation and emergency cardiovascular care science with treatment recommendations, Pediatrics, 2010, 126:e1319-e1344

${ }^{2}$ GRADE refers to the system for grading the quality of evidence and the strength of recommendations. 
Table 1. Categories of evidence

\begin{tabular}{|l|l|}
\hline \multicolumn{1}{|c|}{ Level of Evidence } & \multicolumn{1}{c|}{ Rationale } \\
\hline High & $\begin{array}{l}\text { Further research is very unlikely to change confidence in the } \\
\text { estimate of effect. }\end{array}$ \\
\hline Moderate & $\begin{array}{l}\text { Further research is likely to have an important impact on } \\
\text { confidence in the effect. }\end{array}$ \\
\hline Low & $\begin{array}{l}\text { Further research is very likely to have an important impact on } \\
\text { estimate of effect and is likely to change the estimate. }\end{array}$ \\
\hline Very low & Any estimate of effect is very uncertain. \\
\hline
\end{tabular}

The assessment of quality of a set of studies (the majority of those included) was based on the following criteria:

- Study design: randomized controlled trials (RCTs) - individual or cluster RCTs; nonrandomized experimental studies; or observational studies.

- Limitations in methods: risk of selection bias - allocation concealment in RCTs and comparability of groups in observational studies; risk of measurement bias - blinding or objective outcomes; extent of loss to follow-up; appropriateness of analysis - intention to treat, adjustment for cluster randomization in cluster RCTs, adjustment for confounding in observational studies.

- Consistency: similarity of results across the set of available studies - direction of effect estimates, most studies showing meaningful benefit or unacceptable harm.

- Precision: based on the width of confidence intervals (CIs) of the pooled effects across studies.

- Directness (also called generalizability or external validity): whether the majority of evidence was from studies conducted in low- and middle-income countries, and evaluated interventions relevant to the identified questions.

Additional considerations included the magnitude of the effect, presence or absence of a dose-response gradient and direction of plausible biases. GRADE tables from systematic reviews were cross-checked, and a discussion on benefits and harms, values and preferences and costs was drafted. Recommendations were formulated and drafted in accordance with procedures outlined in the WHO Handbook for Guideline Development ${ }^{1}$, and guided by the quality of evidence using the GRADE methodology.

\footnotetext{
${ }^{1}$ WHO. Handbook for guideline development. Geneva, WHO, 2010.
} 
In drafting the recommendations, the WHO Steering Group used the summaries of evidence for the critical outcomes, quality of evidence, risks and benefits of implementing the recommendations, values and preferences and costs.

The draft recommendations, evidence summaries, GRADE tables and information on benefits and risks, values and preferences, and costs were presented to the GDG at its meeting held at WHO headquarters in Geneva, Switzerland, in June 2011. The GDG reviewed and discussed this information to finalize the recommendations. Most decisions were based on the evidence from RCTs or observational human studies. Where these were not available, evidence from relevant animal studies was used. Where the GDG determined that there was insufficient evidence, consensus within the group was used as the basis of the recommendation.

The decisions on the final recommendations and their strength were made by consensus or, where necessary, by vote. In deciding on the strength of the recommendations, the GDG was guided by the agreed-upon assessment criteria described in Table 2 below.

Table 2. Assessment criteria for the strength of recommendations

\begin{tabular}{|l|l|}
\hline \multicolumn{1}{|c|}{$\begin{array}{c}\text { Strength of } \\
\text { recommendation }\end{array}$} & \multicolumn{1}{c|}{ Rationale } \\
\hline Strong & $\begin{array}{l}\text { The GDG is confident that the desirable effects of adherence to the } \\
\text { recommendation outweigh the undesirable effects. }\end{array}$ \\
\hline Weak & $\begin{array}{l}\text { The GDG concludes that the desirable effects of adherence to a } \\
\text { recommendation probably outweigh the undesirable effects. } \\
\text { However, the recommendation is only applicable to a specific } \\
\text { group, population or setting OR where new evidence may result in } \\
\text { changing the balance of risk to benefit OR where the benefits may } \\
\text { not warrant the cost or resource requirements in all settings. }\end{array}$ \\
\hline $\begin{array}{l}\text { No } \\
\text { recommendation }\end{array}$ & $\begin{array}{l}\text { Further research is required before any recommendation can be } \\
\text { made. }\end{array}$ \\
\hline
\end{tabular}

When the GDG felt that the benefits of a recommendation outweighed the harms in some situations but not in others, the situation to which the recommendation is relevant was explicitly stated.

The recommendations, their levels of strength and remarks were circulated to the GDG and peer reviewers for comments before finalization.

REVIEW AND UPDATE OF THE RECOMMENDATIONS

These recommendations will be regularly updated as more evidence is collated and analysed on a continuous basis, with major reviews and updates at least every 5 years. The next major update will be considered in 2015 under the oversight of the WHO Guidelines 
Review Committee. These recommendations will form part of a technical series of the evidence behind several guidelines to be produced by MCA over the coming years.

\section{RECOMMENDATIONS}

\section{IMMEDIATE CARE AFTER BIRTH}

\section{- RECOMMENDATION 1}

In newly-born term or preterm babies who do not require positive-pressure ventilation, the cord should not be clamped earlier than one minute after birth $\mathbf{1}$.

(Strong recommendation, based on moderate to high quality evidence for benefits in reducing the need for blood transfusion and increasing body iron stores and very low quality evidence for risk of receiving phototherapy for hyperbilirubinaemia)

\section{Remark:}

"Not earlier than one minute" should be understood as the lower limit supported by published evidence. WHO recommendations for the prevention of postpartum haemorrhage $^{2}$ recommend that the cord should not be clamped earlier than is necessary for applying cord traction, which the GDG clarified would normally take around 3 minutes.

When newly-born term or preterm babies requires positive-pressure ventilation, the cord should be clamped and cut to allow effective ventilation to be performed.

(Weak recommendation, based on the consensus of the WHO GDG in the absence of evidence in babies who need PPV)

Remark:

If there is experience in providing effective PPV without cutting the cord, ventilation can be initiated before cutting the cord.

\section{EVIDENCE FOR RECOMMENDATION 1}

\footnotetext{
1 "Not earlier than one minute" should be understood as the lower limit supported by published evidence. WHO Recommendations for the prevention of postpartum haemorrhage (Fawole B et al. Geneva, WHO, 2007) state that the cord should not be clamped earlier than is necessary for applying cord traction, which the GDG clarified would normally take around 3 minutes.

2 FAWOLE B ET AL. WHO RECOMMENDATIONS FOR THE PREVENTION OF POSTPARTUM HAEMORRHAGE: RHL GUIDELINE (LAST REVISED: 1 MAY 2010). THE WHO REPRODUCTIVE HEALTH LIBRARY. GENEVA, WHO, 2010.
} 
Question for systematic review: In normal or depressed ${ }^{1}$ newly-born babies (P), does late cord clamping (I) compared with standard management $(\mathrm{C})$ improve outcome (O)?

\section{Summary of evidence}

Twenty-one RCTs that evaluated the effects of late cord clamping in normal neonates in the delivery room were identified. Of these, 10 included term neonates (Ceriani Cernadas, 2006; Ceriani Cernadas et al., 2010; Chaparro et al., 2006; Emhamed, van Rheenen \& Brabin, 2004; Geethanath et al., 1997; McDonald, 1996; Nelson et al., 1980; Oxford Midwives Research Group, 1991; van Rheenen et al., 2007; Venâncio et al., 2008) while 11 trials enrolled predominantly preterm infants (Baenziger et al., 2007; Hofmeyr et al., 1988; Hofmeyr et al., 1993; Kinmond et al., 1993; Kugelman et al., 2007; McDonnell \& Henderson-Smart, 1997; Mercer, 2006; Oh et al., 2002; Rabe et al., 2000; Strauss et al., 2008; Ultee et al., 2008). No studies in depressed neonates were identified. There was considerable heterogeneity in the clamping time and positioning of the infant before clamping between the included studies. The clamping time in the "late clamping" group varied from 30 seconds to 5 minutes after birth, or until the cord stopped pulsating.

Eight randomized trials (Baenziger et al., 2007; Hofmeyr et al., 1988; Hofmeyr et al., 1993; Kugelman et al., 2007; McDonnell et al., 1997; Mercer, 2006; Oh et al., 2002; Rabe et al., 2000), mostly from high-income country settings, that evaluated the effect of late cord clamping on mortality during initial hospital stay were identified. All these trials included only preterm neonates. The quality of evidence for this outcome was graded as low. Overall, there was no difference in the risk of mortality between the late and early cord clamping groups (RR $0.73,95 \%$ CI 0.30 to 1.81 ).

Four RCTs (Hofmeyr et al., 1988; Hofmeyr et al., 1993; Kugelman et al., 2007; Mercer, 2006) evaluated the incidence of intraventricular haemorrhage in preterm neonates who underwent late cord clamping. The quality of evidence for this outcome was graded as low. No difference was observed in the risk of intraventricular haemorrhage between the late and early cord clamping groups (RR $0.70,95 \%$ CI 0.16 to 2.93 ).

Three studies (Ceriani Cernadas, 2006; McDonald, 1996; Nelson et al., 1980) that examined the risk of admission in a neonatal intensive care unit (NICU) immediately after birth in term infants were summarized. The quality of evidence for this outcome was graded as low. Late cord clamping did not affect the risk of admission in a NICU (RR 0.95, 95\% CI 0.51 to 1.78).

A total of six randomized trials (Kinmond et al., 1993; Kugelman et al., 2007; McDonnell \& Henderson-Smart, 1997; Mercer, 2006; Rabe et al., 2000; Strauss et al., 2008) have looked at the rates of anaemia requiring transfusion during initial hospital stay in preterm neonates. The quality of evidence for this outcome was graded as moderate. On average, there was about 32\% reduction in the need for blood transfusion with late cord clamping (RR 0.68, 95\% CI 0.51 to 0.92). An observational study (Farrar et al., 2011) that reported the mean change in birth weight following late cord clamping in term infants supports this finding. The mean change in weight was $116 \mathrm{~g}$ [95\% CI 72 to 160] after a delay in cord clamping of about 2 to 5 minutes after birth. This change approximates to $110 \mathrm{ml}$ (95\% CI 69 to 152) of total transfusion volume which is roughly $40 \%$ of total blood volume in these infants.

\footnotetext{
${ }^{1} \mathrm{~A}$ "depressed" newborn is a baby not breathing or crying at birth who usually has poor muscle tone and heart rate below 100 beats/minute.
} 
Three studies (Ceriani Cernadas et al., 2010; Chaparro et al., 2006; van Rheenen et al., 2007) evaluated the effect of late cord clamping on the risk of anaemia at 6 months of age in term infants. The quality of evidence for this outcome was graded as moderate. No significant difference was found in the rates of anaemia between the late and early clamping groups (RR 0.87, 95\% CI 0.69 to 1.10). Four trials from low- and middle-income country settings (Ceriani Cernadas et al., 2010; Chaparro et al., 2006; Geethanath et al., 1997; Venâncio et al., 2008) estimated the serum ferritin concentrations at 3-6 months of age in term neonates. The quality of evidence for this outcome was graded as high. The mean difference (MD) in mean serum ferritin concentration was $12.5 \mathrm{mcg} /$ litre higher in infants in the late clamping group (95\% CI 5.72 to 19.3$)$.

Three trials (Ceriani Cernadas, 2006; Emhamed, van Rheenan \& Brabin, 2004; van Rheenen et al., 2007) reported the effect of timing of cord clamping on the incidence of polycythaemia - haematocrit more than $65 \%$ - in term infants. The quality of evidence for this outcome was graded as low. There was no difference in the risk of polycythaemia following late cord clamping (RR 2.39, 95\% CI 0.72 to 7.93). Seven RCTs (Emhamed, van Rheenan \& Brabin, 2004; McDonald, 1996; Nelson et al., 1980; Oxford Midwives Research Group, 1991; Rabe et al., 2000; Strauss et al., 2008; Ultee et al., 2008) examined the risk of receiving phototherapy for hyperbilirubinaemia following late clamping in term and preterm neonates. In a majority of these studies, the criteria used for phototherapy were not strictly defined. On average, there was a 33\% increase in the risk of receiving phototherapy for hyperbilirubinaemia. The quality of evidence for this outcome was graded as very low.

In conclusion, there is moderate to high quality evidence that late clamping of the umbilical cord is associated with lower risk of anaemia requiring transfusion in preterm infants and with higher serum ferritin levels at follow-up in term neonates. There is low quality evidence that late cord clamping has no effect on mortality and severe morbidity. There is very low quality evidence that the intervention is associated with a higher risk of receiving phototherapy for hyperbilirubinaemia in the immediate neonatal period.

\section{CONSIDERATIONS IN FORMULATING RECOMMENDATION 1}

Balance of benefits and harms: The currently available evidence from normal term and preterm infants shows significant benefits of late cord clamping in reducing the need for blood transfusions and increasing body iron stores. These benefits were considered to outweigh the potential harm, i.e. higher risk of receiving phototherapy for hyperbilirubinaemia.

It was not possible to balance benefits and harms in depressed neonates requiring resuscitation at birth because none of the included studies enrolled such neonates. The GDG felt that it may be difficult to initiate resuscitation without clamping and cutting the cord.

Values and preferences: Health care providers and policy-makers from both low- and middle-income as well as high-income countries are likely to give a high value to the benefits noted in the reduced need for blood transfusion in preterm infants. Benefits in infant body-iron stores would be valued highly because of the association between iron status and cognitive development. Many health care providers may not feel comfortable providing PPV without clamping and cutting the cord. 
Costs: Late cord clamping in the delivery room does not have any cost implications, but may reduce the costs for blood transfusions.

\section{- RECOMMENDATION 2}

Newly-born babies who do not breathe spontaneously after thorough drying should be stimulated by rubbing the back $2-3$ times before clamping the cord and initiating positive-pressure ventilation.

(Weak recommendation, based on consensus of WHO GDG in the absence of published evidence)

\section{EVIDENCE FOR RECOMMENDATION 2}

Question for systematic review: In neonates not breathing spontaneously after birth (P), does additional stimulation (I) compared with thorough drying alone (C) reduce the need for PPV (0)?

\section{Summary of evidence}

No human studies were identified that compared the effects of additional tactile stimulation with only drying/suctioning in neonates requiring assistance at birth.

Two animal studies have looked at the effect of tactile stimulation on spontaneous breathing at around the time of birth in animals. The first study (Faridy, 1983) described the steps of resuscitation employed by maternal rats with their offspring, including increasing levels of stimulation of their newborns. The other study (Scarpelli, Condorelli \& Cosmi, 1977) demonstrated that mechanical cutaneous stimulation induces spontaneous breathing in apnoeic fetal lambs.

In conclusion, there is very weak evidence from animal studies that tactile stimulation helps in initiating spontaneous breathing after birth. Thorough drying of the newborn is considered to be a stimulation of the baby, and there is no clear evidence that additional stimulation beyond thorough drying is helpful.

\section{CONSIDERATIONS IN FORMULATING RECOMMENDATION 2}

Balance of benefits and harms: There is a lack of evidence on the relative merits and disadvantages of providing additional tactile stimulation at birth in depressed human neonates. Evidence from animal studies indicates that tactile stimulation might play a role in establishing spontaneous breathing in depressed newborns and avoid the use and possible complications of PPV. On the other hand, providing additional stimulation could delay the initiation of PPV.

Values and preferences: Given the lack of evidence for benefits or harms, health care providers are likely to continue with the existing policy of providing additional stimulation at the time of birth in depressed neonates.

Costs: Providing additional stimulation at birth does not have any cost implications. 


\section{- RECOMmendation 3}

In neonates born through clear amniotic fluid who start breathing on their own after birth, suctioning of the mouth and nose should not be performed.

(Strong recommendation, based on high quality evidence of lower oxygen saturation and low quality evidence of lower Apgar scores)

In neonates born through clear amniotic fluid who do not start breathing after thorough drying and rubbing the back 2-3 times, suctioning of the mouth and nose should not be done routinely before initiating positive-pressure ventilation. Suctioning should be done only if the mouth or nose is full of secretions.

(Weak recommendation, based on the consensus of the WHO GDG in the absence of evidence in babies who need PPV and harmful effects of suctioning in healthy neonates)

\section{EVIDENCE FOR RECOMMENDATION 3}

Question for systematic review: In depressed neonates with clear amniotic fluid (P), does suctioning of the mouth and nose (I) before starting PPV versus no suctioning (C) improve outcome $(0)$ ?

\section{Summary of evidence}

No study was located - observational or interventional - that evaluated the effects of suctioning of the mouth and nose at birth in depressed neonates. Therefore, evidence from studies that examined the effects of oral and nasal suctioning in normal, healthy neonates was summarized.

Three studies (Gungor et al., 2005; Gungor et al., 2006; Waltman et al., 2004) examined the effect of oral and nasal suctioning at birth on oxygen saturation (Sp02) levels at 5 minutes of life. The quality of evidence for this outcome was graded as high. The pooled MD in oxygen saturation levels was $9.8 \%$ lower $(95 \%$ CI $-10.2 \%$ to $-9.4 \%$ ) in those who underwent oropharyngeal or nasopharyngeal suctioning. Another study (Carrasco, Martell \& Estol, 1997) also looked at the effect of oral/nasal suctioning on SpO2 levels, but the results of this study could not be included in the pooled effect because of incomplete data. The study also reported significantly lower Sp02 levels in those who underwent oropharyngeal or nasopharyngeal suctioning at birth than those who did not undergo suctioning.

Three RCTs (Gungor et al., 2005; Gungor et al., 2006; Waltman et al., 2004) evaluated the effect of oropharyngeal suctioning on Apgar scores at 5 minutes of life. The quality of evidence for this outcome was graded as low. There was a significant reduction in the proportion of infants with normal Apgar scores in the suctioning group compared to the group with no suctioning (RR $0.54,95 \%$ CI 0.29 to $1.00, \mathrm{p}=0.049$ ).

An observational study with no control group (Cordero \& Hon, 1971) reported high incidences of cardiac arrhythmias $(7 / 46 ; 15.2 \%)$ and apnoea $(5 / 46 ; 10.9 \%)$ following 
suctioning with a nasogastric tube attached to a de Lee trap; however, no such events were observed in infants suctioned with a bulb syringe.

In conclusion, routine oral and nasal suctioning in normal healthy neonates immediately after birth is associated with lower oxygen saturation levels (high quality evidence) and lower Apgar scores (low quality evidence).

\section{CONSIDERATIONS IN FORMULATING RECOMMENDATION 3}

Balance of benefits and harms: The available evidence shows that routine oral and nasal suctioning at the time of birth might be associated with potential harms - lower oxygen saturation levels and lower Apgar scores - in normal healthy neonates. It is clear that neonates who begin breathing spontaneously after birth should not be suctioned. No apparent benefits were observed with routine oronasopharyngeal suctioning in any of the included studies. However, there is no evidence of harmful or beneficial effects of suctioning in depressed neonates born through clear amniotic fluid.

Values and preferences: Given the lack of benefits and the evidence for potential harms, health care providers and policy-makers from low- and middle-income and high-income country settings are likely to give a low value to the practice of routine oronasopharyngeal suctioning in newly-born infants. However, it is a widely-used practice which has been promoted actively for decades as an important step before PPV. Routine suctioning may delay the start of effective PPV. Whether initiating PPV without suctioning increases complications of air leak or ineffective ventilation has not been studied. Most providers would feel that effective PPV may be hindered if the mouth and nose are full of secretions.

Costs: Routine suctioning of mouth and nose requires suction machines, suction catheters or bulb syringes.

\section{- RECOMMENDATION 4}

In the presence of meconium-stained amniotic fluid, intrapartum suctioning of the mouth and nose at the delivery of the head is not recommended.

(Strong recommendation, based on low quality evidence for no benefits or harms in clinical outcomes, and the potential risks involved)

\section{EVIDENCE FOR RECOMMENDATION 4}

Question for systematic review: In neonates born through meconium-stained amniotic fluid (P), does intrapartum oropharyngeal and nasopharyngeal suctioning at the delivery of the head (I) compared with no intrapartum suctioning (C) prevent MAS and mortality (0)?

\section{Summary of evidence}


One RCT (Vain et al., 2004) evaluated the effect of intrapartum suctioning on mortality of neonates born through meconium-stained amniotic fluid. The quality of evidence for this outcome was graded as low. There was no significant difference in the risk of mortality between the group of neonates who underwent intrapartum suctioning and the control group of infants (RR 2.22, 95\% CI 0.69 to 7.22). Another study that used historical controls (Carson et al., 1976) found no significant difference in the number of deaths due to MAS following implementation of intrapartum suctioning (RR 0.31, 95\% CI 0.02 to 5.67).

Four studies (Carson et al., 1976; Falciglia, 1988; Falciglia et al., 1992; Vain et al., 2004) examined the effect of intrapartum suctioning in the presence of meconium on the incidence of MAS. The quality of evidence for this outcome was graded as low. There was no significant difference in the incidence of MAS following intrapartum suctioning (RR 1.07, $95 \%$ CI 0.80 to 1.44 ).

Two studies (Falciglia, 1988; Vain et al., 2004) evaluated the effect of intrapartum suctioning on the rates of perinatal asphyxia in infants born through meconium-stained amniotic fluid. The quality of evidence for this outcome was graded as low. No significant difference was observed in the proportion of infants with Apgar scores of $\leq 6$ (RR 0.88, 95\% CI 0.63 to 1.23). Another study (Carson et al., 1976) reported mean Apgar scores of 9 and 6.6 respectively in infants who underwent intrapartum suctioning and in those who did not undergo the procedure. The study authors did not elaborate whether the difference was statistically significant.

One RCT (Vain et al., 2004) reported the effect of intrapartum suctioning on the incidence of pulmonary air leaks. The quality of evidence for this outcome was graded as low. There was no significant difference in the incidence of pneumothorax between the two groups of infants (RR 0.99, 95\% CI 0.20 to 4.90 ).

The same RCT (Vain et al., 2004) reported the duration of hospital stay of infants with MAS in the intervention and control groups. The quality of evidence for this outcome was graded as low. No significant difference was found between the two groups of infants (MD -0.8 days, $95 \%$ CI -4.8 to 3.2). Another study (Carson et al. , 1976) reported the mean duration of stay in all those who survived until discharge. The mean duration was found to be 8 and 9.7 days respectively in those who underwent suctioning and the control infants. The study authors neither provided the standard deviations nor did they elaborate whether the difference was statistically significant.

In conclusion, there is low quality evidence that routine intrapartum suctioning does not reduce the risk of mortality, MAS or perinatal asphyxia in infants born through meconiumstained amniotic fluid. There is low quality evidence that the procedure does not have harmful effects such as pneumothorax.

\section{CONSIDERATIONS IN FORMULATING RECOMMENDATION 4}

Balance of benefits and harms: The evidence available does not show any significant benefits in mortality, MAS, perinatal asphyxia or air leaks following intrapartum suctioning in infants born through meconium. However, the majority of these studies were conducted in settings with low incidence of MAS and/or perinatal asphyxia and availability of endotracheal intubation for depressed infants.

Values and preferences: Health care providers and policy-makers from low- and middleincome and high-income country settings are not likely to give a high value to routine 
intrapartum suctioning in neonates born through meconium-stained amniotic fluid because of lack of benefits.

Costs: Not recommending intrapartum suctioning in neonates born through meconiumstained amniotic fluid would save resources.

\section{- RECOMMENDATION 5}

In neonates born through meconium-stained amniotic fluid who start breathing on their own, tracheal suctioning should not be performed.

(Strong recommendation, based on moderate to low quality evidence for no benefits in mortality or MAS in vigorous neonates)

In neonates born through meconium-stained amniotic fluid who start breathing on their own, suctioning of the mouth or nose is not recommended.

(Weak recommendation, based on consensus of WHO GDG in the absence of published evidence on benefits and harms)

In neonates born through meconium-stained amniotic fluid who do not start breathing on their own, tracheal suctioning should be done before initiating positivepressure ventilation.

(Weak situational recommendation, based on very low quality evidence of benefit in reducing MAS, relevant to settings where endotracheal intubation is possible)

In neonates born through meconium-stained amniotic fluid who do not start breathing on their own, suctioning of the mouth and nose should be done before initiating positive-pressure ventilation.

(Weak recommendation, based on consensus of WHO GDG in the absence of published evidence on benefits and harms)

\section{EVIDENCE FOR RECOMMENDATION 5}

Question for systematic review: In neonates born through meconium-stained amniotic fluid (P), does oropharyngeal and/or endotracheal suctioning (I) compared with no suctioning of either oropharynx or trachea (C) prevent MAS and mortality (O)?

\section{Summary of evidence:}

Oropharyngeal suctioning in infants born through meconium-stained amniotic fluid

No studies were identified that evaluated the effects of oropharyngeal suctioning in either vigorous or depressed neonates born through meconium-stained amniotic fluid. 


\section{Tracheal suctioning in vigorous neonates}

Two RCTs (Daga et al., 1994; Wiswell et al., 2000) evaluated the effect of endotracheal suctioning on the risk of mortality in vigorous neonates born through meconium-stained amniotic fluid. The quality of evidence for this outcome was graded as low. There were only a few events in both the studies (total of 1 and 5 deaths respectively). Tracheal suctioning did not reduce the risk of mortality (RR $0.96,95 \%$ CI 0.22 to 4.25 ).

Two trials (Linder et al., 1988; Wiswell et al., 2000) examined the effect of tracheal suctioning on the risk of MAS in vigorous neonates. The quality of evidence for this outcome was graded as moderate. No significant difference was observed in the incidence of MAS (RR $1.33,95 \%$ CI 0.82 to 2.14 ).

Two trials (Daga et al., 1994; Linder et al., 1988) reported the effect of tracheal suctioning on the incidence of air leaks, such as pneumothorax or pulmonary interstitial emphysema, in infants born through meconium-stained amniotic fluid. The quality of evidence for this outcome was graded as very low. Only a few events occurred in either of the groups in both the studies. There was no significant difference in the incidence of air leaks between the two groups (RR 0.87, 95\% CI 0.16 to 4.92 ).

One RCT (Daga et al., 1994) reported the effect of tracheal suctioning on the incidence of HIE. The quality of evidence for this outcome was graded as very low. No significant difference was observed in the incidence of HIE between the two groups of infants (RR 2.65, 95\% CI 0.30 to 23.8 ).

\section{Tracheal suctioning in depressed neonates}

No RCTs that compared the effects of tracheal suctioning with no suctioning in depressed neonates born through meconium-stained amniotic fluid were found. Three before-andafter studies (Falciglia, 1988; Gregory et al., 1974; Wiswell, Tugell \& Turner, 1990) compared the effect of tracheal suctioning on the risk of death and/or MAS in neonates born through meconium. All three studies reported lower risk of either neonatal mortality or deaths attributable to MAS following implementation of routine tracheal suctioning with or without intrapartum suctioning. However, it is unclear whether the reduction in mortality was because of the advances in perinatal care over the years or because of tracheal suctioning. The incidence of MAS was found to be lower in the suctioned infants in only one study (Wiswell, Tugell \& Turner, 1990); the other two studies (Falciglia, 1988; Gregory et al., 1974) reported no change in the risk of MAS. Another study (Ting \& Brady, 1975) elucidated the risk factors for developing respiratory distress in neonates born through meconium-stained amniotic fluid in a case-control design. This study reported that the only difference between the symptomatic and asymptomatic groups was the history of tracheal suctioning in the delivery room. All these studies included both depressed and vigorous neonates born through meconium-stained amniotic fluid.

Four observational studies (Al Takroni et al., 1998; Gupta Bhatia \& Mishra, 1996; Peng, Gutcher \& Van Dorsten, 1996; Yoder, 1994) evaluated the effect of combined intrapartum oral suctioning and postnatal tracheal suctioning in depressed neonates. These studies did not include any 'control' group, and reported that MAS continued to occur despite tracheal suctioning.

In conclusion, there is moderate to very low quality evidence from randomized trials that tracheal suctioning does not reduce the risk of mortality, MAS or air leaks in vigorous infants born through meconium-stained amniotic fluid. On the other hand, evidence from 
retrospective studies indicates that tracheal suctioning might be associated with lower risk of mortality in depressed infants born through meconium-stained amniotic fluid.

\section{CONSIDERATIONS IN FORMULATING RECOMMENDATION 5}

Balance of benefits and harms: Currently available evidence does not show any significant benefits in mortality, MAS, air leaks or HIE with tracheal suctioning in vigorous infants born through meconium-stained amniotic fluid. There is some evidence that tracheal suctioning might reduce the risk of mortality in depressed infants born through meconium-stained amniotic fluid. There is no evidence for either benefits or harms with nasal or oropharyngeal suctioning in newborns born through meconium-stained amniotic fluid.

Values and preferences: Given these considerations, health care providers and policymakers from low- and middle-income country settings are not likely to give a high value to oropharyngeal or tracheal suctioning in vigorous neonates born through meconium-stained amniotic fluid. However, they are likely to value tracheal suctioning for depressed neonates born through meconium-stained amniotic fluid.

Costs: Tracheal suctioning requires the availability of skilled personnel capable of performing endotracheal intubation as well as suction catheters, laryngoscopes and suction devices. The observed lack of benefits does not justify the additional costs involved in implementation of this practice in resource-limited settings.

\section{- Recommendation 6}

In settings where mechanical equipment to generate negative pressure for suctioning is not available and a newly-born baby requires suctioning, a bulb syringe (single-use or easy to clean) is preferable to a mucous extractor with a trap in which the provider generates suction by aspiration.

(Weak recommendation, based on no evidence of one being better than the other for the neonate, and potential risks for health care providers with use of the mucous extractor)

\section{Remarks:}

- Only single-use bulb syringes or mucous extractors should be used; if this is not possible, use only those devices that can be easily and thoroughly cleaned.

- Deep suctioning should never be done.

\section{EVIDENCE FOR RECOMMENDATION 6}

Question for systematic review: In neonates who require suction to clear their airways $(\mathrm{P})$, what is the safety and efficacy (O) of different types of suction devices (I/C)?

\section{Summary of evidence}

Five studies (Cohen-Addad, Chatterjee \& Bautista, 1987; Cordero \& Hon, 1971; Dunn et al., 2001; Hageman et al., 1988; Locus, Yeomans \& Crosby, 1990) from high-income country settings have compared the effects of oral and/or pharyngeal suctioning by a DeLee mucous 
extractor with that by a bulb syringe. None of these studies have, however, described the method used for generating negative pressure while using the DeLee catheter.

Two studies (Cohen-Addad, Chatterjee \& Bautista, 1987; Hageman et al., 1988) evaluated the effect of using a mucous extractor or bulb syringe on the risk of mortality due to MAS. Both studies reported no significant difference in the risk of mortality between the two groups.

Four studies (Cohen-Addad, Chatterjee \& Bautista, 1987; Dunn et al., 2001; Hageman et al., 1988; Locus, Yeomans \& Crosby, 1990) compared the incidence of MAS in infants who underwent suctioning with a DeLee trap with those who underwent suctioning with a bulb syringe. No significant difference in the risk of MAS was observed in any of these studies.

Only one study (Cordero \& Hon, 1971) reported the incidence of severe adverse events following nasopharyngeal suctioning with a DeLee catheter or bulb syringe in normal neonates after birth. The study reported that seven infants developed bradyarrhythmias and five developed apnoea following suctioning by a catheter attached to a DeLee trap $(n=46)$; none in the bulb syringe group $(n=41)$ had either arrhythmia or apnoea. The effects for both the outcomes were not statistically significant (arrhythmia: RR 13.4, 95\% CI 0.79 to 227.7; apnoea: RR 9.83; 95\% CI 0.56 to 172.5 ).

None of the identified studies compared the effects of suctioning by use of mechanical suctioning devices (wall mounted or foot operated) with that by either bulb syringe or DeLee mucous extractor.

Animal studies: One animal study (Gage et al., 1981) compared the effect of suctioning by a catheter with that of suctioning by a bulb syringe on the distribution of meconium in the airways of anaesthetized kittens. The authors used scintigraphy to estimate the distribution of the meconium labelled with technetium-99m. The study reported a significant reduction in radioactivity with catheter suctioning compared with bulb suctioning $(43 \%$ and $1 \%$ decrease respectively; $\mathrm{P}<0.05$ ).

In conclusion, there is very low quality evidence that suctioning with a mucous extractor does not reduce the risk of mortality, MAS or severe adverse events such as arrhythmias/apnoea when compared with bulb suctioning. Evidence from one animal study suggests that DeLee catheter suctioning might be more effective in removing the meconium from the trachea than suctioning with a bulb syringe.

\section{CONSIDERATIONS IN FORMULATING RECOMMENDATION 6}

Balance of benefits and harms: The currently available evidence from clinical studies does not show any significant benefits or harms in the risk of mortality, MAS or severe adverse events with a bulb syringe compared with DeLee catheter suctioning.

A potential harm associated with the use of a DeLee catheter is the risk of inadvertent aspiration of fluids into the resuscitator's mouth. None of the included studies had specified the method used for generating negative pressure - whether by oral suction by health workers or by mechanical devices - while using the DeLee mucous extractor. The modified version of the DeLee mucous extractor has a filter that prevents aspiration of the contents into the mouth of the health worker. Bulb syringes, on the other hand, are difficult to clean; they can easily become a source of cross-infection, if not cleaned properly. 
Values and preferences: Given these considerations, policy-makers are likely to be equivocal regarding the optimal suctioning device to be used in newly-born infants requiring assistance at birth. Health care providers are likely to prefer a method that does not pose a risk of infection to them.

Costs: Both DeLee suction catheters and bulb syringes are relatively inexpensive and available.

\section{POSITIVE-PRESSURE VENTILATION}

\section{- RECOMMENDATION 7}

In newly-born babies who do not start breathing despite thorough drying and additional stimulation, positive-pressure ventilation should be initiated within one minute after birth.

(Strong recommendation, based on very low quality evidence from observational studies)

\section{EVIDENCE FOR RECOMMENDATION 7}

Question for systematic review: In neonates who fail to breathe after birth (P), should PPV be initiated within one minute after birth if the baby has not started breathing after initial steps of resuscitation (I) as compared to a later time (C) for preventing HIE and mortality (0)?

\section{Summary of evidence}

Only one very low quality observational study (Berglund et al., 2008) in human neonates related to this question was identified. This was a retrospective chart review of cases of suspected delivery-related malpractice in a high-income country setting. Mortality in neonates in whom PPV was initiated within one minute after birth was not significantly lower than those in whom PPV was initiated at a later time (RR 0.62, 95\% CI 0.09 to 4.04). However, there were only seven cases in the comparison group, and many infants who received PPV within one minute after birth were not resuscitated using standard guidelines in the next minutes after birth.

\section{Animal studies}

No controlled trial that compared the effects of early and late initiation of PPV in asphyxiated newborn animals was identified. Observational studies (Hernandez-Andrade et al., 2005; Kaneko, 2003; Thorngren-Jerneck et al., 2001; Yan et al., 2009) showed that after complete occlusion of the cord in animal foetuses, electrocortical activity is reduced on average within about 90 seconds, cerebral blood flow is reduced after about 3 minutes, arterial hypotension sets in by about 7 minutes and cardiac arrest occurs within about 15 minutes.

Two animal studies (Borke et al., 2006; Haney et al., 2005) showed a significant improvement in myocardial function, and another study (Cavus et al., 2006) showed an improvement in cerebral oxygenation following initiation of PPV in asphyxiated animals. 
However, none of these studies specifically addressed the issue of timing of initiating PPV in asphyxiated animals.

\section{CONSIDERATIONS IN FORMULATING RECOMMENDATION 7}

Balance of benefits and harms: Currently available evidence from human studies is not helpful in determining the timing of PPV initiation. Evidence from animal studies indicates that important blood pressure and cerebral blood flow reductions occur 7-10 minutes, and cardiac arrest occurs within 15 minutes, after cord occlusion. Initiation of PPV has been found to be associated with a significant improvement in myocardial function and cerebral oxygenation in animals. These two pieces of evidence indicate that the window of opportunity to reverse the consequences of asphyxia is small. Since the period of asphyxia before birth is variable and not precisely known in most cases, the GDG agreed with the currently recommended practice of initiating PPV if the baby does not start breathing within one minute after birth.

Values and preferences: Given the considerations of benefits and harms, health care providers and policy-makers are likely to prefer initiating PPV early in asphyxiated neonates.

Costs: There is no difference in costs between early and late initiation of PPV.

\section{- RECOMMENDATION 8}

In newly-born term or preterm ( $>32$ weeks gestation) babies requiring positivepressure ventilation, ventilation should be initiated with air.

(Strong recommendation, based on moderate quality evidence for benefits in mortality and no evidence for significant harms)

\section{Remarks:}

- For preterm babies born at or before 32 weeks gestation, it is preferable to start ventilation with $30 \%$ rather than $100 \%$ oxygen. If this is not possible, ventilation should be started with air.

- For neonates who continue to have a heart rate of $<60 /$ minute after 30 seconds of adequate ventilation with air, progressively higher concentrations of oxygen should be considered. However, if oxygen is not available, ventilation should be continued with air.

- Pulse oximetry is desirable to decide on the need for supplemental oxygen and to monitor the needed concentration of oxygen. However, pulse oximetry is not easily available in resource-limited settings, and its use by a single health worker performing basic newborn resuscitation is difficult. 


\section{EVIDENCE FOR RECOMMENDATION 8}

Question for systematic review: In newborns who require resuscitation at birth (P), is PPV with air (I) more effective than that with higher concentrations of oxygen (C) in reducing subsequent mortality and HIE (0)?

\section{Summary of evidence}

Seven RCTs (Bajaj, 2005; Ramji et al., 1993; Ramji et al., 2003; Saugstad, Rootwelt \& Aalen, 1998; Vento, 2001a; Vento et al., 2001b; Vento et al., 2003) compared the effect of resuscitation using air with the use of $100 \%$ oxygen on mortality in newly-born infants. Some of the data not published in the original papers was extracted from a systematic review which directly received these data from the investigators (Rabi, Rabi \& Yee, 2007). Of the seven studies, four are quasi-RCTs (Bajaj, 2005; Ramji et al., 1993; Ramji et al., 2003; Saugstad, Rootwelt \& Aalen, 1998) conducted in low- and middle-income country settings. Some of the trials included only term infants, but most of the evidence comes from studies that included $20 \%$ to $35 \%$ preterm infants. Most preterm infants included were of greater than 32 weeks gestation. Four studies reported the risk of mortality in the first week of life; the other three reported mortality until 28 days or discharge. The quality of evidence for this outcome was graded as moderate. The pooled effect was 30\% reduction $195 \%$ CI $3 \%$ to $49 \%$ ) in the risk of mortality following resuscitation with air compared with $100 \%$ oxygen.

A total of four studies (Bajaj, 2005; Ramji et al., 1993; Ramji et al., 2003; Saugstad, Rootwelt \& Aalen, 1998) evaluated the effect of room air resuscitation on the risk of HIE (stage 2 or 3 ) in the neonatal period. The quality of evidence for this outcome was graded as low. No significant difference was found in the risk of HIE between the groups of infants resuscitated with air or $100 \%$ oxygen (OR $0.89,95 \%$ CI 0.66 to 1.19 ).

One study (Vento et al., 2003) examined the effect on the time of onset of spontaneous breathing in depressed neonates. The quality of evidence for this outcome was graded as low. The mean difference in time of onset to spontaneous breathing was 1.5 minutes less (95\% CI -2.02 to -0.98) in those who were resuscitated with air. Two other studies (Bajaj, 2005; Saugstad, Rootwelt \& Aalen, 1998) had also reported this outcome, but their results could not be included in the meta-analysis because of incomplete data. While one of these studies reported a significantly shorter time to onset of spontaneous breathing in infants resuscitated with air (Saugstad, Rootwelt \& Aalen, 1998), the other did not report any significant difference between the two groups (Bajar, 2005).

One study (Saugstad, Rootwelt \& Aalen, 1998) evaluated the risk of long-term neurodevelopmental outcomes following resuscitation with air. The quality of evidence for this outcome was graded as very low. There was no difference between the air and $100 \%$ oxygen groups in the risk of cerebral palsy at 18 to 24 months of age (OR 1.38, 95\% CI 0.46 to 4.10$)$.

In conclusion, there is moderate quality evidence that resuscitation using air reduces the risk of mortality and the time of onset of spontaneous breathing in neonates born after 32 weeks gestation when compared with resuscitation using $100 \%$ oxygen. However, it does not reduce the risk of HIE during the neonatal period or adverse neurodevelopmental outcomes at a later age.

Studies in preterm infants with $\leq 32$ weeks gestation 
Two additional RCTs and one observational study were identified comparing resuscitation with air to that using higher oxygen concentrations in only preterm infants $\leq 32$ weeks gestation. Lundstrom and colleagues (1995) showed that 74\% of infants resuscitated with room air were successfully stabilized without the need for supplemental oxygen. Cerebral blood flow at 2 hours after birth was significantly higher in neonates resuscitated with room air compared with those resuscitated with $80 \%$ oxygen. Wang and colleagues (2008) showed that resuscitation with room air failed to achieve the arbitrary oxygen saturation target $0 \mathrm{f} 70 \%$ at 3 minutes and $80 \%$ at 5 minutes, and all neonates needed supplemental oxygen. Similar results were reported in an observational study (Dawson et al., 2009).

Two RCTs conducted only in preterm infants $\leq 28$ weeks gestation compared initiation of resuscitation using 30\% oxygen with that using 90\% oxygen. Escrig and colleagues (2008) showed that resuscitation in extremely preterm infants can be safely initiated with $30 \%$ oxygen which is then adjusted to the infant's needs. Vento and colleagues (2009) reported that initiation of resuscitation with $30 \%$ oxygen resulted in better clinical outcomes (days supplemental oxygen required, days of mechanical ventilation, bronchopulmonary dysplasia) than with $90 \%$ oxygen.

\section{CONSIDERATIONS IN FORMULATING RECOMMENDATION 8}

Balance of benefits and harms: The available evidence shows that using air for resuscitation is associated with significant benefits in short-term mortality but not in longterm developmental outcomes in term and preterm neonates $>32$ weeks gestation. In most of the studies, $100 \%$ oxygen was used as a backup for babies not responding to resuscitation with air after 90 seconds after birth. However, the proportion of nonresponders in the group initially randomized to resuscitation with air was similar to that in the group allocated to $100 \%$ oxygen. No apparent harms have been reported with room air resuscitation in term and preterm babies of $>32$ weeks gestation in any of the included trials.

Available evidence suggests that the majority of preterm babies $\leq 32$ weeks gestation may be stabilized with resuscitation using air. However, a substantial proportion of these infants need resuscitation with higher oxygen concentrations. It appears that the outcome is better if resuscitation is initiated with $30 \%$ rather than $90 \%$ oxygen.

Values and preferences: Given the benefits observed in the risk of mortality and lower costs involved in administering it, health care providers and policy-makers from both lowand middle- income and high-income country settings are likely to give a high value to the use of room air for resuscitating newly-born infants.

Costs: Use of air requires significantly less resources than $100 \%$ oxygen; it can be administered at even the most remote health care facilities. Additional resources are required to provide care to extremely premature infants. 


\section{- RECOMmENDATION 9}

In newly-born babies requiring positive-pressure ventilation, ventilation should be provided using a self-inflating bag and mask.

(Weak recommendation, based on very low quality evidence for no benefits or harm in clinical outcomes and possible benefits in ease of use)

Remark:

In an emergency situation where a self-inflating bag is not functional, mouth-to-tube and mask or mouth-to-mask can be used for providing PPV.

\section{EVIDENCE FOR RECOMMENDATION 9}

Question for systematic review: In neonates who require PPV (P), does ventilation with a self-inflating bag and mask (I) compared with mouth-to-tube and mask (or mouth-tomask) ventilation $(\mathrm{C})$ improve outcome $(\mathrm{O})$ ?

\section{Summary of evidence}

Two studies compared the effects of using a self-inflating bag with mouth-to-tube and mask for providing PPV in neonates. One of the studies was a quasi-randomized trial (Massawe et al., 1996), while the other had a before-and-after design (Bang et al., 2005); both were conducted in low- and middle-income country settings, and reported the effect on mortality in the neonatal period. The quality of evidence for this outcome was graded as very low. There was no significant difference in the risk of mortality between the group of neonates resuscitated with bag and mask and that resuscitated with mouth-to-tube and mask (Pooled RR $1.01,95 \%$ CI 0.39 to 2.60 ).

Only one of the studies (Massawe et al., 1996) evaluated the effects on the time to first cry and Apgar scores. The quality of evidence for both these outcomes was graded as very low. There was no significant difference in either the proportion of infants who cried within 5 minutes after birth (RR 1.27, 95\% CI 0.93 to 1.73) or who had Apgar scores of 4 or more at 5 minutes after birth (RR $0.99,95 \%$ CI 0.86 to 1.14). The study found no significant difference in the risk of convulsions between the two groups (RR $0.92,95 \%$ CI 0.52 to 1.64). The quality of evidence for this outcome was graded as very low.

In conclusion, there is very low quality evidence that there is no difference between PPV using a self-inflating bag and using mouth-to-tube and mask in terms of risk of mortality, convulsions, onset of crying and Apgar score in the first 5 minutes after birth.

\section{Descriptive studies/surveys/in vitro studies:}

One study published as a report (PATH, 2006) included training a large number of health workers in Indonesia in mouth-to-tube and mask ventilation, and found a lower subsequent mortality rate.

Two surveys (Ariawan et al., 2011; Coffey, Kelly \& Tsu, 2007) reported the views of health care providers on the use of bag and mask and tube and mask in neonatal resuscitation. One of these surveys (Coffey, Kelly \& Tsu, 2007) reported that bag and mask is much easier to use than tube and mask as the latter requires the user to constantly bend forward and blow for 10 to 15 minutes. The before-and-after study by Bang and colleagues (2005) reported 
the same difficulty with tube and mask ventilation. On the other hand, Ariawan and colleagues (2011) found that tube and mask is much easier to clean and more portable, and is therefore preferred by health professionals. One study (Roberts \& Day, 1973) described bacterial growth in blood-agar plates after the experimenter exhaled on them through neonatal endotracheal tubes under conditions simulating resuscitation of neonates.

\section{CONSIDERATIONS IN FORMULATING RECOMMENDATION 9}

Balance of benefits and harms: The currently available evidence from clinical studies does not show any significant benefits or harms in mortality, convulsions, or Apgar scores at 5 minutes after birth with the use of bag and mask ventilation when compared with tube and mask ventilation. Other studies and surveys indicate that bag and mask is possibly easier to use and might carry less risk of transmitting infections when compared with mouth-to-tube and mask.

Values and preferences: Given these considerations, health providers are likely to prefer a self-inflating bag and mask for PPV in depressed neonates because of ease of use, while policy-makers would probably prefer mouth-to-tube and mask because of lower costs.

Costs: Self-inflating bags are more expensive than mouth-to-tube devices.

\section{- RECOMMENDATION 10}

\section{In newly-born babies requiring positive-pressure ventilation, ventilation should be initiated using a face-mask interface.}

(Strong recommendation, based on limited availability and lack of experience with nasal cannula, ${ }^{1}$ despite low quality evidence for benefits of nasal cannula in reducing need for chest compressions and endotracheal intubation)

\section{Remark:}

Currently, there is insufficient evidence to recommend the use of other interfaces.

\section{EVIDENCE FOR RECOMMENDATION 10}

Question for systematic review: In neonates receiving PPV (P), does the use of nasal cannula(I) versus a face-mask interface (C) improve outcome (O)?

\section{Summary of evidence}

A single quasi-RCT (Capasso et al., 2005) from a high-income country setting compared the effects of using a short bi-nasal cannula with that of a face mask interface for providing PPV in neonates. The study used a Rendell-Baker mask which has been shown to be the least

\footnotetext{
${ }^{1}$ Nasal cannula is a semi-rigid tube which creates a pressure seal in the nostrils.
} 
effective during neonatal resuscitation and is no longer used in most delivery rooms. There is very low quality evidence of no significant difference in the risks of mortality (RR 0.49, 95\% CI 0.21 to 1.11), Apgar scores of greater than 7 at 5 minutes of life (RR 1.04, 95\% CI 1.0 to 1.08) or pulmonary air leaks (RR $0.66,026$ to 1.68). The study reported a significantly lower need for intubation (RR $0.1,95 \%$ CI 0.02 to 0.44 ) and chest compressions (RR 0.2 , $95 \%$ CI 0.08 to 0.51 ) in infants receiving PPV via nasal prongs. The quality of evidence for these outcomes was graded as low.

In conclusion, there is low quality evidence that providing PPV via nasal cannula reduces the need for intubation and chest compressions during resuscitation.

\section{CONSIDERATIONS IN FORMULATING RECOMMENDATION 10}

Balance of benefits and harms: Currently available evidence from clinical studies does not show any significant benefits or harms in mortality, air leaks and Apgar scores at 5 minutes of life following PPV delivered via nasal cannula or face mask interface. The use of nasal cannula may reduce the need for endotracheal intubation and chest compressions. This effect was, however, observed in comparison with a mask that is no longer used for providing respiratory support at birth.

Values and preferences: Given the limited experience of using nasal cannula as the interface for ventilation, most health care providers are likely to still prefer the face mask interface.

Costs: Short bi-nasal cannula is currently more expensive and is not easily available in most delivery rooms in resource-restricted settings.

\section{- RECOMMENDATION 11}

In newly-born babies requiring positive-pressure ventilation, adequacy of ventilation should be assessed by measurement of the heart rate after 60 seconds of ventilation with visible chest movements.

(Strong recommendation, based on very low quality evidence from observational data in newborn humans and animals that heart rate is the first indicator of recovery)

Remark:

Where feasible, continuous or repeated monitoring of the heart rate should be carried out during resuscitation.

\section{EVIDENCE FOR RECOMMENDATION 11}

Question for systematic review: In neonates who require PPV (P), is measuring heart rate and chest movements (I) compared with chest movements alone (C) better to assess ventilation $(0)$ ?

\section{Summary of evidence}


No study was identified that directly studied the effects of measuring heart rate and chest movements with assessment of chest movements alone after initiation of PPV in newly-born infants requiring assistance at birth. Therefore, observational studies that have evaluated the roles of either heart rate or chest expansion measurement individually in infants requiring PPV at birth were reviewed.

Six studies (Ginott et al., 1980; Palme-Kilander \& Tunnell, 1993; Perlman \& Risser, 1995; Saugstad et al., 2005; Schubring et al., 1976; Yam et al., 2011) described the effect of resuscitation on heart rates in asphyxiated neonates. All these studies indicated that improvement in heart rate is a sensitive indicator of adequate resuscitation.

Two observational studies (Poulton et al., 2011; Schmölzer et al., 2010) evaluated the role of measurement of chest expansion as an indicator of adequate ventilation in neonates requiring PPV in the delivery room. Both studies correlated visual estimation of tidal volume, as measured by chest expansion, with the measured tidal volume. The studies showed that there is poor agreement between clinical assessment and measured volume. In a majority of the instances, the resuscitators underestimated the delivered tidal volume.

\section{Animal studies:}

One animal study (Dawes, 1968) elucidated the sequence of events following induced asphyxia in fetal monkeys and rabbits by not allowing them to breathe after birth. The animals developed primary apnoea within 30 seconds of birth associated with bradycardia and gasping efforts after about one minute that continued for several minutes. Resuscitation efforts at any point up to or after last gasp, if successful, were associated with a prompt increase in heart rate which was the first sign of recovery. Another animal study (AngellJames \& Daly, 1978) showed that artificial lung inflation invariably resulted in tachycardia in anaesthetized dogs with experimentally-induced apnoea and bradycardia.

In conclusion, there is evidence from observational studies that an increase in heart rate accompanies successful ventilation in depressed neonates. On the other hand, there is evidence from observational studies that visual inspection of chest movements alone is not a reliable indicator of VT.

\section{CONSIDERATIONS IN FORMULATING RECOMMENDATION 11}

Balance of benefits and harms: Currently available evidence indicates that an increase in heart rate is a good indicator of response to resuscitation. Observation of chest expansion, as the only sign to assess ventilation, risks underestimating the delivered VTs and therefore inducing lung injury in asphyxiated neonates receiving PPV.

Values and preferences: Given the evidence for potential benefits, health care providers and policy-makers are likely to prefer using heart rate together with chest movements for assessing ventilation.

Costs: Measurement of heart rate during resuscitation by birth attendants requires additional training. 


\section{- ReCOMmendation 12}

In newly-born babies who do not start breathing within one minute after birth, priority should be given to providing adequate ventilation rather than to chest compressions.

(Strong recommendation, based on very low quality evidence from observational studies that ventilation is the most effective intervention for asphyxiated neonates)

Remark:

When a second skilled provider is present, and the neonate continues to have a heart rate of less than 60/minute after 1 minute of PPV, consider chest compressions in addition to PPV.

\section{EVIDENCE FOR RECOMMENDATION 12}

Question for systematic review: In neonates requiring resuscitation after birth (P), is $\boldsymbol{P P V}$ alone (I) as effective as PPV and chest compressions (C) in reducing mortality (O)?

Summary of evidence: Only one observational study (Perlman \& Risser, 1995) relevant to the research question was identified. This study examined risk factors for failure of bag and mask ventilation, defined as the need for chest compressions and/or epinephrine, during resuscitation. The study reported that in about two thirds of the infants requiring chest compressions, an improvement in heart rate was observed only after institution of proper respiratory management (effective ventilation with higher pressures and/or endotracheal tube placement).

Animal studies:

One animal study (Dannevig et al., 2011) randomized newborn pigs into three groups ventilation for 30 seconds, 1 minute or 1.5 minutes before initiation of cardiac compressions - and compared the effect on return of spontaneous circulation. The study found no difference between the first two groups; there was, however, a significant delay in the return of spontaneous circulation in the third group (initiation of chest compressions at 1.5 minutes).

Two other studies (Berg et al., 1999; Berg et al., 2000) in a piglet model relevant to cardiac arrest in older children were identified. These interventional studies compared the effect of PPV alone with PPV plus chest compressions in 2-3 month-old asphyxiated piglets with cardiac arrest. One study (Berg et al., 2000) showed a significantly reduced incidence of neurologically normal survival at 24 hours in the group resuscitated with PPV alone (RR $0.60,95 \%$ CI 0.36 to 0.99 ). The other study (Berg et al., 1999) also showed a trend towards reduction in the incidence of intact survival at 24 hours after resuscitation (RR $0.20,95 \% \mathrm{CI}$ 0.03 to 1.31 ).

There is evidence from observational studies that heart rate increases within 30-60 seconds of effective ventilation (see Recommendation 11). There is very low quality evidence (summarized above) that failure of increase in heart rate in many cases may be due to ineffective ventilation. However, if the heart rate is absent or very low after 1 minute of adequate PPV, the addition of chest compressions to PPV might be beneficial. 


\section{CONSIDERATIONS IN FORMULATING RECOMMENDATION 12}

Balance of benefits and harms: Currently available evidence indicates a benefit of adding chest compressions, if the heart rate is absent or very low after 1 minute of adequate ventilation. No harm of this approach has been reported, but a single provider cannot perform effective PPV and chest compressions at the same time.

Values and preferences: Given these considerations, most health care providers are likely to give a high value to initiation of chest compressions in asphyxiated neonates whose heart rate does not increase after 1 minute of PPV. However, this intervention is feasible only when more than one skilled provider is available.

Costs: Administration of chest compressions requires two skilled providers at every birth, which would have high costs in most resource-limited settings.

\section{STOPPING RESUSCITATION}

\section{- RECOMMENDATION 13}

In newly-born babies with no detectable heart rate after 10 minutes of effective ventilation, resuscitation should be stopped.

(Strong recommendation, based on evidence of unlikely benefits for the baby)

In newly-born babies who continue to have a heart rate below $60 /$ minute and no spontaneous breathing after 20 minutes of resuscitation, resuscitation should be stopped.

(Weak situational recommendation, based on very low quality evidence for unlikely benefits for the baby in resource-limited settings)

\section{EVIDENCE FOR RECOMMENDATION 13}

Question for systematic review: In neonates who continue to have no heart rate or severe bradycardia despite resuscitation (P), should resuscitation efforts be stopped after 10 minutes (I) as opposed to 20 minutes or longer (C)?

\section{Summary of evidence}

No study was identified, either observational or interventional, that compared the effect of stopping resuscitation efforts at 10 minutes after birth with stopping at a later time in neonates with asystole or severe bradycardia in the delivery room. Therefore, the outcome of neonates who continued to have asystole or severe bradycardia after several minutes of resuscitation was reviewed. 
Nine studies, mostly of retrospective cohort or case-series design from high-income country settings (Casalaz, Marlow \& Spiedel, 1998; Haddad et al., 2000; Harrington et al., 2007; Jain et al., 1991; Koppe \& Kleiverda, 1984; Laptook et al., 2009; Patel \& Beeby, 2004; Socol, Garcia \& Riter, 1994; Yeo \& Tudehope, 1994), reported outcomes of interest in neonates with asystole at 10 minutes after birth. The studies reported a very high risk of mortality, which ranged from $48 \%$ to $88 \%$ in studies with a sample size of at least 10 infants (Haddad et al., 2000; Jain et al., 1991; Laptook et al., 2009; Patel \& Beeby, 2004). The study reporting the lowest mortality risk (Laptook et al., 2009) included neonates who underwent wholebody hypothermia in a multi-centre randomized trial, which may have reduced the risk of mortality in these infants. Most of the survivors had moderate to severe neurological disability. The quality of these studies is very low; they do not mention the number of infants with asystole who were not resuscitated, do not specify the method of assessing the duration or quality of resuscitation efforts, and have variable developmental assessment of survivors and a significant loss to follow-up.

No studies reporting the outcome of infants with severe bradycardia after 10 minutes of resuscitation were found. However, five studies (Casalaz, Marlow \& Spiedel,1998; Haddad et al., 2000; Laptook et al., 2009; Nelson \& Ellenberg, 1981; Nelson et al., 2011) looked at the outcomes of infants with Apgar scores of 1-3 at 10 minutes after birth. None of these studies specifically reported the heart rates of the included infants; it could be assumed that the infants had a detectable heart rate at 10 minutes of life and that the majority of them would have severe bradycardia (heart rate less than 60/minute). The risk of mortality was $19 \%$ to $54 \%$ in studies with a sample size of at least 10 infants (Haddad et al., 2000; Laptook et al., 2009). Only two studies reported long-term outcomes - disability in 7 of 12 (Laptook et al., 2009) and 2 of 2 survivors (Nelson \& Ellenberg, 1981).

\section{CONSIDERATIONS IN FORMULATING RECOMMENDATION 13}

Balance of benefits and harms: Currently available evidence from observational studies indicates that neonates with asystole at 10 minutes after birth are at an extremely high risk of mortality or abnormal neurological outcomes. The outcome in neonates with severe bradycardia at 10 minutes is likely to be poor in the majority of cases.

Values and preferences: Given the high rates of adverse outcomes in infants with asystole at 10 minutes, health care providers and policy-makers are likely to give a high value to stopping the resuscitation efforts at 10 minutes after birth in such infants. However, in neonates who have a detectable heart rate, health care providers might want to continue resuscitation efforts if advanced care is available. Where possible, the parents' views on resuscitation should be obtained and supported.

Costs: Cessation of resuscitation efforts in neonates who have asystole at 10 minutes after birth may save health system resources. 
The GDG identified the following questions for future research:

- What is the effect of implementation of these basic newborn resuscitation guidelines on practice in low- and middle-income countries?

- What is the effect of different training methodologies for improving skills for basic newborn resuscitation on performance of health workers?

- What is the effect of video recordings of the care provided to a newborn at birth as a teaching and evaluation tool?

- What is the trainability and performance of different categories of health workers in conducting resuscitation?

- What are the feasibility, safety and efficacy of resuscitation done without cutting the umbilical cord in improving newborn outcomes?

- What is the best time to clamp the umbilical cord in term and preterm babies who start breathing on their own within the first minute after birth $(1,2,3,4$ or 5 minutes, or when the cord becomes flat) after a vaginal delivery or a caesarean section?

- What is the risk of serious hyperbilirubinaemia associated with late cord clamping?

- What is the efficacy of stimulation in addition to thorough drying for newborns who do not start breathing on their own in avoiding PPV?

- In settings with a risk of asphyxia and MAS, what are the safety and efficacy of intrapartum suctioning in babies with meconium-stained amniotic fluid in improving newborn outcomes?

- In settings with a risk of asphyxia and MAS, what are the safety and efficacy of suctioning before initiating PPV in babies with meconium-stained amniotic fluid who do not start breathing on their own in improving newborn outcomes?

- What are the safety and efficacy of suctioning of the mouth and nose before initiating PPV in babies with clear amniotic fluid who do not start breathing on their own in improving newborn outcomes?

- Which is the best interface for providing PPV (e.g. nasal cannula, nasal mask or nasopharyngeal prongs, compared with a face mask)?

- What are simple and reliable ways to measure heart rate that do not interfere with provision of PPV? 
- What are simpler, low-cost ways of administering blended oxygen for preterm babies $<32$ weeks gestation?

- Does keeping a resuscitated neonate under a warmer improve or worsen outcome?

- How can whole body or head cooling be done safely for babies who have experienced intrapartum hypoxic-ischemic events in low-resource settings?

A strategy for effective uptake of guidelines requires definition of the key messages, the audiences and the actions for them to take. The key messages of these guidelines are the recommendations listed in the Executive Summary (and the text above). By designating some recommendations as "strong", the GDG is confident that their implementation will yield significant health benefits, outweighing any potential harm. Although for the remaining "weak" recommendations the situation is less clear, the GDG still felt that the recommendations made are the best possible options for resource-limited settings. The implementation of all recommendations on basic resuscitation will be promoted as a package. With regard to monitoring and evaluation of their impact on quality of care, priority will be given to the strong recommendations. The guidelines also highlight areas where evidence is limited, and further research is warranted.

Monitoring and evaluation will be built into implementation, in order to provide important lessons for uptake and continued implementation. An integrated implementation, monitoring and evaluation framework is proposed in Table 3. 
Table 3. Implementation, monitoring and evaluation framework for the second edition of the WHO guidelines on basic newborn resuscitation

\begin{tabular}{|c|c|c|c|c|}
\hline Level & $\begin{array}{l}\text { Type of } \\
\text { activities }\end{array}$ & $\begin{array}{l}\text { Description of } \\
\text { activities }\end{array}$ & Responsibilities & Indicator \\
\hline \multicolumn{5}{|c|}{ GLOBAL } \\
\hline & Input & $\begin{array}{l}\text { Revise all WHO } \\
\text { publications } \\
\text { (including practice } \\
\text { guides, training } \\
\text { materials, job aids, } \\
\text { quality of care } \\
\text { assessment tools) } \\
\text { addressing care of } \\
\text { the newborn } \\
\text { infant at birth }\end{array}$ & $\begin{array}{l}\text { WHO /HQ } \\
\text { Secretariat }\end{array}$ & $\begin{array}{l}\text { Number of } \\
\text { updated WHO } \\
\text { publications }\end{array}$ \\
\hline & Input & $\begin{array}{l}\text { Seek endorsement } \\
\text { of relevant global } \\
\text { players in } \\
\text { newborn health } \\
\text { (e.g. UNICEF, } \\
\text { UNFPA, } \\
\text { international } \\
\text { NGOs) }\end{array}$ & $\begin{array}{l}\text { WHO/HQ } \\
\text { Secretariat }\end{array}$ & $\begin{array}{l}\text { Number of } \\
\text { international } \\
\text { organizations } \\
\text { endorsing the } \\
\text { guidelines }\end{array}$ \\
\hline & Impact & $\begin{array}{l}\text { Document } \\
\text { reduction in global } \\
\text { number of } \\
\text { neonatal deaths } \\
\text { due to asphyxia }\end{array}$ & $\begin{array}{l}\text { WHO/HQ } \\
\text { Secretariat }\end{array}$ & $\begin{array}{l}\text { Estimates of } \\
\text { asphyxia-specific, } \\
\text { and early (within } \\
\text { first week) } \\
\text { neonatal } \\
\text { mortality (NMR) }\end{array}$ \\
\hline \multicolumn{5}{|c|}{ REGIONAL } \\
\hline & Input & $\begin{array}{l}\text { Dissemination of } \\
\text { and capacity } \\
\text { building on the use } \\
\text { of tools (e.g. } \\
\text { practice guides, } \\
\text { training materials, } \\
\text { job aids and } \\
\text { quality of care } \\
\text { assessment tools) } \\
\text { containing new } \\
\text { basic newborn } \\
\text { resuscitation } \\
\text { recommendations }\end{array}$ & $\begin{array}{l}\text { WHO Regional } \\
\text { Offices }\end{array}$ & $\begin{array}{l}\text { Number of } \\
\text { countries } \\
\text { adopting tools } \\
\text { related to basic } \\
\text { newborn } \\
\text { resuscitation }\end{array}$ \\
\hline
\end{tabular}




\begin{tabular}{|c|c|c|c|c|}
\hline \multicolumn{5}{|l|}{ NATIONAL } \\
\hline & Input & $\begin{array}{l}\text { Development or } \\
\text { revision of } \\
\text { national standards } \\
\text { and guidelines } \\
\text { reflecting WHO } \\
\text { recommendations }\end{array}$ & $\begin{array}{l}\text { Ministries of } \\
\text { health or } \\
\text { delegated } \\
\text { authorities }\end{array}$ & $\begin{array}{l}\text { Number of } \\
\text { countries with } \\
\text { national } \\
\text { standards and } \\
\text { guidelines } \\
\text { reflecting WHO } \\
\text { recommendations }\end{array}$ \\
\hline & Impact & $\begin{array}{l}\text { Reduce national } \\
\text { neonatal and early } \\
\text { neonatal mortality } \\
\text { rates }\end{array}$ & Member States & $\begin{array}{l}\text { NMR, early NMR } \\
\text { from nationally } \\
\text { representative } \\
\text { surveys }\end{array}$ \\
\hline \multicolumn{5}{|c|}{ SERVICE DELIVERY LEVEL } \\
\hline & Input & $\begin{array}{l}\text { Build and maintain } \\
\text { competencies of } \\
\text { health workers } \\
\text { attending births to } \\
\text { perform newborn } \\
\text { resuscitation }\end{array}$ & $\begin{array}{l}\text { Ministries of } \\
\text { health, facility } \\
\text { managers and } \\
\text { partners }\end{array}$ & $\begin{array}{l}\text { Proportion of } \\
\text { health } \\
\text { professionals } \\
\text { attending births } \\
\text { trained in } \\
\text { newborn } \\
\text { resuscitation }\end{array}$ \\
\hline & Input & $\begin{array}{l}\text { Make available and } \\
\text { maintain in good } \\
\text { working condition } \\
\text { equipment and } \\
\text { supplies required } \\
\text { for basic newborn } \\
\text { resuscitation }\end{array}$ & $\begin{array}{l}\text { Ministries of } \\
\text { health, facility } \\
\text { managers and } \\
\text { partners }\end{array}$ & $\begin{array}{l}\text { Proportion of } \\
\text { health care } \\
\text { facilities with } \\
\text { maternity } \\
\text { services that } \\
\text { have a functional } \\
\text { bag and mask }\end{array}$ \\
\hline & Outputs & $\begin{array}{l}\text { Ensure that every } \\
\text { birth is attended } \\
\text { by a health worker } \\
\text { proficient in and } \\
\text { equipped for } \\
\text { newborn } \\
\text { resuscitation }\end{array}$ & $\begin{array}{l}\text { Ministries of } \\
\text { health, facility } \\
\text { managers and } \\
\text { partners }\end{array}$ & $\begin{array}{l}\text { Proportion of } \\
\text { births assisted by } \\
\text { a health worker } \\
\text { trained in and } \\
\text { equipped for } \\
\text { newborn } \\
\text { resuscitation }\end{array}$ \\
\hline & Impact & $\begin{array}{l}\text { Reduce early } \\
\text { neonatal deaths } \\
\text { (within } 7 \text { days) of } \\
\text { infants weighing } \\
2500 \text { g or more in } \\
\text { facilities }\end{array}$ & $\begin{array}{l}\text { Facility } \\
\text { managers, } \\
\text { health workers } \\
\text { and } \\
\text { community } \\
\text { health workers }\end{array}$ & $\begin{array}{l}\text { Proportion of } \\
\text { newborn infants } \\
\text { with a birth } \\
\text { weight } \geq 2500 \mathrm{~g} \\
\text { alive on } 7^{\text {th }} \text { day of } \\
\text { life }\end{array}$ \\
\hline
\end{tabular}

In the context of an increasingly complex international health architecture with multiple players in the areas of advocacy and technical assistance to countries in need, it is vital that 
messages and approaches to strengthen newborn resuscitation with its benefit of reducing early neonatal mortality are consistent. In this regard, WHO will work with partners such as United Nations agencies, international nongovernmental organizations (NGOs) and bilateral development agencies to achieve consistency of messages. Furthermore, at the implementation level, whether national or sub-national, there needs to be ownership of the recommendations. WHO will support country processes to adopt these guidelines into national policies. Efforts to improve health workers' knowledge and skills need to be well coordinated, especially with respect to training programmes. WHO will support governments in this coordination and will facilitate alignment of partners with national programmes.

\section{Global Actions}

The first steps in implementation after the final approval of the guidelines will be to revise all WHO publications that deal with newborn resuscitation. These include the clinical guides for maternal, newborn and child health: Pregnancy, childbirth, postpartum and newborn care; Managing complications of pregnancy and childbirth; Managing newborn problems; and Pocket book on hospital care for children. The revision will include the development of simple flow charts that can be used as job aids by health workers to perform basic newborn resuscitation. The new guidelines will also serve as a standard for neonatal care on initiation of breathing and resuscitation that can be used to assess the adequacy of programmes and quality of care. The existing training package, Essential newborn care course, will also be updated, as well as the related tool for computer-assisted learning. These tools will be made available as printed materials or in electronic format.

WHO will reach out to global partners to obtain their endorsement of the guidelines and tools derived from the guidelines in order to facilitate their dissemination and impact in the global arena. Many organizations active in the area of newborn health have identified newborn resuscitation as a priority intervention; these include, but are not limited to, UNFPA, UNICEF, major bilateral agencies and international NGOs (e.g. Saving Newborn Lives, the American Academy of Pediatrics). At the moment, the clinical guidelines and related training activities on basic newborn resuscitation promoted by these agencies are not consistent, creating a certain level of confusion at country and implementation levels. The above-mentioned advocacy effort will lead to more clarity on basic newborn resuscitation and thus lead to improved performance of health workers and better care for newborn infants. One key collaboration will be that with the Helping Babies Breathe programme.

In addition to active promotion of partnerships for implementation, WHO will also initiate a process of harmonized monitoring and evaluation of the coverage of this critical health care intervention and the quality of care that newborns receive around birth. This will include a globally-agreed monitoring and evaluation framework with standard indicators.

\section{Regional and Country-level Action}

At country level the main step for implementing the recommendations will be to develop national standards and guidelines on newborn resuscitation that take into account the local context. These should be based on the best evidence available, and the present guideline document provides guidance on this matter. The success of the recommendations will be measured by the extent to which countries follow them. In addition, the competencies of health workers in newborn resuscitation will need to be built, both through pre- and in- 
service training; tools related to the guidelines can be used for this purpose. Policy- and decision-makers responsible for health care delivery will need to make the necessary equipment and supplies available. The limited number of supplies required for successful basic newborn resuscitation will facilitate implementation. Ultimately, the impact of the guidelines should be increased coverage of newborn resuscitation for those newborn infants who need it.

Newborn resuscitation is currently a major challenge. Health workers attending births are often not proficient in resuscitation techniques, and equipment may not be available or it may be broken. Also, there is a tendency to over-use resuscitation procedures, if they are available. Therefore, in addition to training of health workers, regular assessments of the quality of care that newborns receive around birth, including appropriate use of resuscitation, are required. The generic tools to assess quality of care derived from these recommendations will be an important element in their implementation. 


\section{REFERENCES}

\section{Recommendation 1}

1. Baenziger 0 et al. The influence of the timing of cord clamping on postnatal cerebral oxygenation in preterm neonates: a randomized, controlled trial. Pediatrics, 2007, 119:455-459.

2. Ceriani Cernadas JM. The effect of timing of cord clamping on neonatal venous hematocrit values and clinical outcome at term: a randomized, controlled trial. Pediatrics, 2006, 117:e779-e786.

3. Ceriani Cernadas JM et al. Efecto del clampeo demorado del cordón umbilical en la ferritina sérica a los seis meses de vida. Estudio clínico controlado aleatorizado [The effect of early and delayed umbilical cord clamping on ferritin levels in term infants at six months of life: a randomized, controlled trial]. Archivos Argentinos de Pediatría, 2010, 108:201-208.

4. Chaparro CM et al. Effect of timing of umbilical cord clamping on iron status in Mexican infants: a randomised controlled trial. Lancet, 2006, 367:1997-2004.

5. Emhamed MO, van Rheenen P, Brabin BJ. The early effects of delayed cord clamping in term infants born to Libyan mothers. Tropical Doctor, 2004, 34:218-222.

6. Farrar $D$ et al. Measuring placental transfusion for term births: weighing babies with cord intact. BJOG: an International Journal of Obstetrics and Gynaecology, 2011, 118:7075.

7. Geethanath RM et al. Effect of timing of cord clamping on the iron status of infants at 3 months. Indian Pediatrics, 1997, 34:103-106.

8. Hofmeyr GJ et al. Periventricular/intraventricular haemorrhage and umbilical cord clamping. Findings and hypothesis. South African Medical Journal, 1988, 73:104-106.

9. Hofmeyr GJ et al. Periventricular/intraventricular hemorrhage following early and delayed umbilical cord clamping: a randomized trial. Online Journal of Current Clinical Trials, 1993, Document Number 110.

10. Kinmond $S$ et al. Umbilical cord clamping and preterm infants: a randomised trial. British Medical Journal, 1993, 306:172-175.

11. Kugelman A et al. Immediate versus delayed umbilical cord clamping in premature neonates born < 35 weeks: a prospective, randomized, controlled study. American Journal of Perinatology, 2007, 24:307-315.

12. McDonald S. Timing of interventions in the third stage of labour. In: Proceedings of the 14th Annual Congress of the Australian Perinatal Society in conjunction with the New Zealand Perinatal Society. Adelaide, Australia, Australian Perinatal Society, 1996, A23.

13. McDonnell M, Henderson-Smart DJ. Delayed umbilical cord clamping in preterm infants: a feasibility study. Journal of Paediatrics and Child Health, 1997, 33:308-310.

14. Mercer JS. Delayed cord clamping in very preterm infants reduces the incidence of intraventricular hemorrhage and late-onset epsis: a randomized, controlled trial. Pediatrics, 2006, 117:1235-1242.

15. Nelson NM et al. A randomized clinical trial of the Leboyer approach to childbirth. New England Journal of Medicine, 1980, 302:655-660.

16. Oh W et al. Delayed cord clamping in extremely low birth weight infants - a pilot randomised controlled trial. Pediatric Research, 2002, 51:365-366.

17. Oxford Midwives Research Group. A study of the relationship between the delivery to cord clamping interval and the time of cord separation. Midwifery, 1991, 7:167-176.

18. Rabe $\mathrm{H}$ et al. A randomised controlled trial of delayed cord clamping in very low birth weight preterm infants. European Journal of Pediatrics, 2000, 159:775-777. 
19. Strauss RG et al. A randomized clinical trial comparing immediate versus delayed clamping of the umbilical cord in preterm infants: short-term clinical and laboratory endpoints. Transfusion, 2008, 48:658-665.

20. Ultee CA et al. Delayed cord clamping in preterm infants delivered at 34-36 weeks' gestation: a randomised controlled trial. Archives of Disease in Childhood - Fetal and Neonatal Edition, 2008, 93:F20-F23.

21. Van Rheenen P et al. Delayed cord clamping and haemoglobin levels in infancy: a randomised controlled trial in term babies. Tropical Medicine \& International Health, 2007, 12:603-616.

22. Venancio SI et al. Efeitos do clampeamento tardio do cordão umbilical sobre os níveis de hemoglobina e ferritina em lactentes aos três meses de vida [Effects of delayed cord clamping on hemoglobin and ferritin levels in infants at three months of age]. Cadernos de Saúde Pública, 2008, 24 Suppl. 2:S323-331.

\section{Recommendation 2}

1. Faridy EE. Instinctive resuscitation of the newborn rat. Respiratory Physiology and Neurobiology, 1983, 51:1-19.

2. Scarpelli EM, Condorelli S, Cosmi EV. Cutaneous stimulation and generation of breathing in the fetus. Pediatric Research, 1977, 11:24-28.

\section{Recommendation 3}

1. Carrasco M, Martell M, Estol PC. Oronasopharyngeal suction at birth: effects on arterial oxygen saturation. Journal of Pediatrics, 1997, 130:832-834.

2. Cordero L Jr, Hon EH. Neonatal bradycardia following nasopharyngeal stimulation. Journal of Pediatrics, 1971, 78:441-447.

3. Gungor $\mathrm{S}$ et al. Oronasopharyngeal suction versus no suction in normal, term and vaginally born infants: a prospective randomised controlled trial. Australian and New Zealand Journal of Obstetrics and Gynaecology, 2005, 45:453-456.

4. Gungor $S$ et al. Oronasopharyngeal suction versus no suction in normal and term infants delivered by elective cesarean section: a prospective randomized controlled trial. Gynecologic and Obstetric Investigation, 2006, 61:9-14.

5. Waltman PA et al. Building evidence for practice: a pilot study of newborn bulb suctioning at birth. Journal of Midwifery \& Women's Health, 2004, 49:32-38.

\section{Recommendation 4}

1. Falciglia HS. Failure to prevent meconium aspiration syndrome. Obstetrics \& Gynecology, 1988, 71:349-353.

2. Falciglia HS et al. Does DeLee suction at the perineum prevent meconium aspiration syndrome? American Journal of Obstetrics and Gynecology, 1992, 167:1243-1249.

3. Carson BS et al. Combined obstetric and pediatric approach to prevent meconium aspiration syndrome. American Journal of Obstetrics and Gynecology, 1976, 126:712-715.

4. Vain NE et al. Oropharyngeal and nasopharyngeal suctioning of meconium-stained neonates before delivery of their shoulders: multicentre, randomised controlled trial. Lancet, 2004, 364:597-602.

\section{Recommendation 5}


1. Al Takroni AM et al. Selective tracheal suctioning to prevent meconium aspiration syndrome. International Journal of Gynaecology \& Obstetrics, 1998, 63:259-263.

2. Daga SR et al. Tracheal suction in meconium-stained infants: a randomized controlled study. Journal of Tropical Pediatrics, 1994, 40:198-200.

3. Falciglia HS. Failure to prevent meconium aspiration syndrome. Obstetrics \& Gynecology, 1988, 71:349-353.

4. Gregory GA et al. Meconium aspiration in infants--a prospective study. Journal of Pediatrics, 1974, 85:848-852.

5. Gupta V, Bhatia BD, Mishra OP. Meconium-stained amniotic fluid: antenatal, intrapartum and neonatal attributes. Indian Pediatrics, 1996, 33:293-297.

6. Linder $\mathrm{N}$ et al. Need for endotracheal intubation and suction in meconium-stained neonates. Journal of Pediatrics, 1988, 112:613-615.

7. Peng TC, Gutcher GR, Van Dorsten JP. A selective aggressive approach to the neonate exposed to meconium-stained amniotic fluid. American Journal of Obstetrics and Gynecology, 1996, 175:296-301, discussion-3.

8. Ting P, Brady JP. Tracheal suction in meconium aspiration. American Journal of Obstetrics and Gynecology, 1975, 122:767-771.

9. Wiswell TE, Tuggle JM, Turner BS. Meconium aspiration syndrome: have we made a difference? Pediatrics, 1990, 85:715-721.

10. Wiswell TE et al. Delivery room management of the apparently vigorous meconiumstained neonate: results of the multicenter, international collaborative trial. Pediatrics, 2000, 105:1-7.

11. Yoder BA. Meconium-stained amniotic fluid and respiratory complications: impact of selective tracheal suction. Obstetrics \& Gynecology, 1994, 83:77-84.

\section{Recommendation 6}

1. Cohen-Addad N, Chatterjee M, Bautista A. Intrapartum suctioning of meconium: comparative efficacy of bulb syringe and DeLee catheter. Journal of Perinatology, 1987, 7:111-113.

2. Cordero L Jr, Hon EH. Neonatal bradycardia following nasopharyngeal stimulation. Journal of Pediatrics, 1971, 78:441-447.

3. Dunn TS et al. DeLee suction. Does it have clinical significance? Journal of Reproductive Medicine, 2001, 46:905-908.

4. Gage JE et al. Suctioning of upper airway meconium in newborn infants. Journal of the American Medical Association, 1981, 246:2590-2592.

5. Hageman JR et al. Delivery room management of meconium staining of the amniotic fluid and the development of meconium aspiration syndrome. Journal of Perinatology, 1988, 8:127-131.

6. Locus P, Yeomans E, Crosby U. Efficacy of bulb versus DeLee suction at deliveries complicated by meconium-stained amniotic fluid. American Journal of Perinatology, 1990, 7:87-91.

\section{Recommendation 7}

1. Berglund $\mathrm{S}$ et al. Neonatal resuscitation after severe asphyxia--a critical evaluation of 177 Swedish cases. Acta Paediatrica, 2008, 97:714-719.

2. Borke WB et al. Reduced left ventricular function in hypoxemic newborn pigs: a strain Doppler echocardiographic study. Pediatric Research, 2006, 59:630-635.

3. Cavus E et al. Brain tissue oxygen pressure and cerebral metabolism in an animal model of cardiac arrest and cardiopulmonary resuscitation. Resuscitation, 2006, 71:97-106. 
4. Haney MF et al. Myocardial systolic function increases during positive-pressure lung inflation. Anesthesia \& Analgesia, 2005, 101:1269-1274.

5. Hernandez-Andrade E et al. Perinatal adaptive response of the adrenal and carotid blood flow in sheep fetuses subjected to total cord occlusion. Journal of Maternal-Fetal \& Neonatal Medicine, 2005, 17:101-109.

6. Kaneko M. Cerebral blood flow and metabolism in relation to electrocortical activity with severe umbilical cord occlusion in the near-term ovine fetus. American Journal of Obstetrics and Gynecology, 2003, 188:961-972.

7. Thorngren-Jerneck K et al. Reduced postnatal cerebral glucose metabolism measured by PET after asphyxia in near term fetal lambs. Journal of Neuroscience Research, 2001, 66:844-850.

8. Yan EB et al. Changes in cerebral blood flow, cerebral metabolites, and breathing movements in the sheep fetus following asphyxia produced by occlusion of the umbilical cord. American Journal of Physiology: Regulatory, Integrative and Comparative Physiology, 2009, 297:R60-R69.

\section{Recommendation 8}

1. Bajaj N. Room air vs. 100 per cent oxygen for neonatal resuscitation: a controlled clinical trial. Journal of Tropical Pediatrics, 2005, 51:206-211.

2. Dawson JA et al. Oxygen saturation and heart rate during delivery room resuscitation of infants $<30$ weeks' gestation with air or $100 \%$ oxygen. Archives of Disease in Childhood: Fetal \& Neonatal Edition, 2009, 94:F87-F91.

3. Escrig $\mathrm{R}$ et al. Achievement of targeted saturation values in extremely low gestational age neonates resuscitated with low or high oxygen concentrations: a prospective, randomized trial. Pediatrics, 2008, 121:875-881.

4. Lundstrom KE, Pryds O, Greisen G. Oxygen at birth and prolonged cerebral vasoconstriction in preterm infants. Archives of Disease in Childhood: Fetal \& Neonatal Edition, 1995, 73:F81-86.

5. Rabi Y, Rabi D, Yee W. Room air resuscitation of the depressed newborn: a systematic review and meta-analysis. Resuscitation, 2007, 72(3):353-363.

6. Ramji S et al. Resuscitation of asphyxic newborn infants with room air or $100 \%$ oxygen. Pediatric Research, 1993, 34:809-812.

7. Ramji S et al. Resuscitation of asphyxiated newborns with room air or $100 \%$ oxygen at birth: a multicentric clinical trial. Indian Pediatrics, 2003, 40:510-517.

8. Saugstad OD, Rootwelt T, Aalen O. Resuscitation of asphyxiated newborn infants with room air or oxygen: an international controlled trial: the Resair 2 study. Pediatrics, 1998, 102:e1.

9. Vento $\mathrm{M}$ et al. Six years of experience with the use of room air for the resuscitation of asphyxiated newly born term infants. Biology of the Neonate, 2001a, 79:261-267.

10. Vento M. Resuscitation with room air instead of $100 \%$ oxygen prevents oxidative stress in moderately asphyxiated term neonates. Pediatrics, 2001b, 107:642-647.

11. Vento $\mathrm{M}$ et al. Oxidative stress in asphyxiated term infants resuscitated with $100 \%$ oxygen. Journal of Pediatrics, 2003, 142:240-246.

12. Vento $\mathrm{M}$ et al. Preterm resuscitation with low oxygen causes less oxidative stress, inflammation, and chronic lung disease. Pediatrics, 2009, 124:e439-e449.

13. Wang CL et al. Resuscitation of preterm neonates by using room air or $100 \%$ oxygen. Pediatrics, 2008, 121:1083-1089.

\section{Recommendation 9}


1. Ariawan I et al. Choosing the appropriate neonatal resuscitation device for village midwives. Journal of Perinatology, 2011, 31(10):664-670.

2. Bang AT et al. Management of birth asphyxia in home deliveries in rural Gadchiroli: the effect of two types of birth attendants and of resuscitating with mouth-to-mouth, tubemask or bag-mask. Journal of Perinatology, 2005, 25 Suppl. 1:S82-S91.

3. Coffey PS, Kelly K, Tsu V. Preferences and practices: use of neonatal resuscitation devices in low-resource settings. Journal of Tropical Pediatrics, 2007, 53:415-419.

4. Massawe A et al. Assessment of mouth-to-mask ventilation in resuscitation of asphyxic newborn babies. A pilot study. Tropical Medicine \& International Health, 1996, 1:865873.

5. PATH. Reducing birth asphyxia through the Bidan di Desa Program in Cirebon, Indonesia: final report submitted by Program for Appropriate Technology in Health (PATH) to Save the Children US. Jakarta, Indonesia, PATH, 2006.

6. Roberts RB, Day RL. Mouth-to-tube resuscitation of the neonate. II. The transmission of bacteria through endotracheal tubes and its prevention. Anesthesia \& Analgesia, 1973, 52:242-245.

\section{Recommendation 10}

1. Capasso L et al. A randomized trial comparing oxygen delivery on intermittent positivepressure with nasal cannulae versus facial mask in neonatal primary resuscitation. Acta Paediatrica, 2005, 94:197-200.

\section{Recommendation 11}

1. Angell-James JE, Daly MD. The effects of artificial lung inflation on reflexly induced bradycardia associated with apnoea in the dog. Journal of Physiology, 1978, 274:349366.

2. Dawes GS. Foetal and neonatal physiology: a comparative study of the changes at birth (p 149). Chicago, Year Book Medical Publishers Inc., 1968.

3. Ginott $\mathrm{N}$ et al. New vacuum stethoscope for immediate monitoring and recording of resuscitation of the newborn. Israel Journal of Medical Sciences, 1980, 16:447-451.

4. Palme-Kilander C, Tunell R. Pulmonary gas exchange during facemask ventilation immediately after birth. Archives of Disease in Childhood, 1993, 68:11-16.

5. Perlman JM, Risser R. Cardiopulmonary resuscitation in the delivery room. Associated clinical events. Archives of Pediatric \& Adolescent Medicine, 1995, 149:20-25.

6. Poulton DA et al. Assessment of chest rise during mask ventilation of preterm infants in the delivery room. Resuscitation, 2011, 82:175-179.

7. Saugstad OD et al. Response to resuscitation of the newborn: early prognostic variables. Acta Paediatrica, 2005, 94:890-895.

8. Schmölzer GM et al. Assessment of tidal volume and gas leak during mask ventilation of preterm infants in the delivery room. Archives of Disease in Childhood: Fetal \& Neonatal Edition, 2010, 95:F393-F397.

9. Schubring $\mathrm{C}$ et al. Oxygen consumption, heart rate, respiratory rate and rectal temperature in healthy newborns during the first two hours after birth. Journal of Perinatal Medicine, 1976, 4:72-77.

10. Yam $\mathrm{CH}$ et al. Heart rate changes during resuscitation of newly born infants $<30$ weeks gestation: an observational study. Archives of Disease in Childhood: Fetal \& Neonatal Edition, 2011, 96:F102-F107. 


\section{Recommendation 12}

1. Berg RA et al. Simulated mouth-to-mouth ventilation and chest compressions (bystander cardiopulmonary resuscitation) improves outcome in a swine model of prehospital pediatric asphyxial cardiac arrest. Critical Care Medicine, 1999, 27:18931899.

2. Berg RA et al. "Bystander" chest compressions and assisted ventilation independently improve outcome from piglet asphyxial pulseless "cardiac arrest". Circulation, 2000, 101:1743-1748.

3. Dannevig I et al. Delayed onset of cardiac compressions in cardiopulmonary resuscitation of newborn pigs with asphyctic cardiac arrest. Neonatology, 2011, 99:153162.

4. Perlman JM, Risser R. Cardiopulmonary resuscitation in the delivery room. Associated clinical events. Archives of Pediatrics \& Adolescent Medicine, 1995, 149:20-25.

\section{Recommendation 13}

1. Casalaz DM, Marlow N, Speidel BD. Outcome of resuscitation following unexpected apparent stillbirth. Archives of Disease in Childhood: Fetal \& Neonatal Edition, 1998, 78:F112-F115.

2. Haddad B et al. Outcome after successful resuscitation of babies born with Apgar scores of 0 at both 1 and 5 minutes. American Journal of Obstetrics and Gynecology, 2000, 182:1210-1214.

3. Jain L et al. Cardiopulmonary resuscitation of apparently stillborn infants: survival and long-term outcome. Journal of Pediatrics, 1991, 118:778-782.

4. Koppe JG, Kleiverda G. Severe asphyxia and outcome of survivors. Resuscitation, 1984, 12:193-206.

5. Laptook AR et al. Outcome of term infants using Apgar scores at 10 minutes following hypoxic-ischemic encephalopathy. Pediatrics, 2009, 124:1619-1626.

6. Nelson KB, Ellenberg JH. Apgar scores as predictors of chronic neurologic disability. Pediatrics, 1981, 68:36-44.

7. Nelson $\mathrm{K}$ et al. The apparently stillborn infant: risk factors, incidence, and neonatal outcome. American Journal of Perinatology, 2011, 28:75-82.

8. Patel H, Beeby PJ. Resuscitation beyond 10 minutes of term babies born without signs of life. Journal of Paediatrics and Child Health, 2004, 40:136-138.

9. Socol ML, Garcia PM, Riter S. Depressed Apgar scores, acid-base status, and neurologic outcome. American Journal of Obstetrics and Gynecology, 1994, 170:991-998, discussion 8-9.

10. Yeo CL, Tudehope DI. Outcome of resuscitated apparently stillborn infants: a ten year review. Journal of Paediatrics and Child Health, 1994, 30:129-133. 
Recommendation 1: Late cord clamping

\begin{tabular}{|c|c|c|c|c|c|c|c|c|}
\hline Outcome & $\begin{array}{l}\text { No. of } \\
\text { studies }\end{array}$ & Design & $\begin{array}{l}\text { Limitations in } \\
\text { methods }\end{array}$ & Precision & Consistency & $\begin{array}{l}\text { General- } \\
\text { izability / } \\
\text { directness }\end{array}$ & $\begin{array}{l}\text { Overall } \\
\text { quality of } \\
\text { evidence }\end{array}$ & $\begin{array}{l}\text { Pooled effect } \\
\text { size[ES] }(95 \% \\
\text { CI) }\end{array}$ \\
\hline $\begin{array}{l}\text { Mortality } \\
\text { (during initial hospital } \\
\text { stay; only preterm } \\
\text { neonates) }\end{array}$ & 8 & RCTs & $\begin{array}{l}\text { No major } \\
\text { limitations }\end{array}$ & $\begin{array}{l}\text { Pooled effect } \\
\text { not } \\
\text { significant, } \\
\text { with wide CI }\end{array}$ & $\begin{array}{l}\text { All } 8 \text { studies } \\
\text { indicate no } \\
\text { effect, but large } \\
\text { variation in ES } \\
(0.14 \text { to } 6.68)\end{array}$ & $\begin{array}{l}\text { Most of the } \\
\text { evidence from } \\
\text { studies in } \\
\text { high-income } \\
\text { country } \\
\text { settings }\end{array}$ & LOW & $\begin{array}{l}\text { RR } 0.73 \\
(0.30 \text { to } 1.81 \text { ) }\end{array}$ \\
\hline $\begin{array}{l}\text { Severe } \\
\text { intraventricular } \\
\text { haemorrhage } \\
\text { (only preterm infants) }\end{array}$ & 4 & RCTs & $\begin{array}{l}\text { No major } \\
\text { limitations }\end{array}$ & $\begin{array}{l}\text { Effect not } \\
\text { significant, } \\
\text { with wide CI }\end{array}$ & $\begin{array}{l}\text { All } 4 \text { studies } \\
\text { indicate no } \\
\text { effect, but ES } \\
\text { varies from } 0.33 \\
\text { to } 2.92\end{array}$ & $\begin{array}{l}\text { Majority of the } \\
\text { evidence from } \\
\text { studies in } \\
\text { high-income } \\
\text { country } \\
\text { settings }\end{array}$ & LOW & $\begin{array}{l}\text { RR 0.70 } \\
(0.16,2.93)\end{array}$ \\
\hline $\begin{array}{l}\text { Anaemia requiring } \\
\text { transfusion } \\
\text { (during initial hospital } \\
\text { stay; only preterm } \\
\text { infants) }\end{array}$ & 6 & RCTs & $\begin{array}{l}\text { Limitations in } \\
\text { measurement }\end{array}$ & $\begin{array}{l}\text { Pooled effect } \\
\text { significant } \\
\text { but upper } \\
\text { limit of CI } \\
\text { close to null }\end{array}$ & $\begin{array}{l}\text { ES of all studies } \\
\text { in same } \\
\text { direction as } \\
\text { pooled ES }\end{array}$ & $\begin{array}{l}\text { From high- } \\
\text { income } \\
\text { country } \\
\text { settings }\end{array}$ & MODERATE & $\begin{array}{l}\text { RR 0.68 } \\
(0.51,0.92)\end{array}$ \\
\hline $\begin{array}{l}\text { Admission in } \\
\text { neonatal intensive } \\
\text { care unit } \\
\text { (only term neonates) }\end{array}$ & 3 & RCTs & $\begin{array}{l}\text { Limitations in } \\
\text { analysis }\end{array}$ & $\begin{array}{l}\text { Effect not } \\
\text { significant, } \\
\text { with wide CI }\end{array}$ & $\begin{array}{l}\text { All } 3 \text { studies } \\
\text { indicate no } \\
\text { effect }\end{array}$ & $\begin{array}{l}\text { Most of the } \\
\text { evidence from } \\
\text { studies in } \\
\text { high-income } \\
\text { country } \\
\text { settings }\end{array}$ & LOW & $\begin{array}{l}\text { RR } 0.95 \\
(0.51 \text { to } 1.78)\end{array}$ \\
\hline $\begin{array}{l}\text { Anaemia at } 6 \text { months } \\
\text { of age } \\
\text { (only term infants) }\end{array}$ & 3 & RCTs & $\begin{array}{l}\text { No major } \\
\text { limitations }\end{array}$ & $\begin{array}{l}\text { Effect not } \\
\text { significant, } \\
\text { with wide CI }\end{array}$ & $\begin{array}{l}\text { All } 3 \text { studies } \\
\text { indicate no } \\
\text { effect }\end{array}$ & $\begin{array}{l}\text { From low- and } \\
\text { middle- } \\
\text { income } \\
\text { country } \\
\text { settings }\end{array}$ & MODERATE & $\begin{array}{l}\text { RR 0.87 } \\
(0.69,1.10)\end{array}$ \\
\hline $\begin{array}{l}\text { Serum ferritin levels } \\
\text { (at } 3 \text { months of age in } \\
2 \text { studies and at } 6 \\
\text { months in } 2 \text { studies; } \\
\text { only term infants) }\end{array}$ & 4 & $\begin{array}{l}\text { Majority } \\
\text { of } \\
\text { evidence } \\
\text { from } \\
\text { RCTs }\end{array}$ & $\begin{array}{l}\text { No major } \\
\text { limitations }\end{array}$ & $\begin{array}{l}\text { Pooled effect } \\
\text { significant, } \\
\text { lower limit of } \\
\text { CI meaningful }\end{array}$ & $\begin{array}{l}\text { ES of studies } \\
\text { with } \geq 75 \% \text { of } \\
\text { total evidence in } \\
\text { the direction as } \\
\text { pooled ES }\end{array}$ & $\begin{array}{l}\text { From low- and } \\
\text { middle- } \\
\text { income } \\
\text { country } \\
\text { settings }\end{array}$ & HIGH & $\begin{array}{l}\text { MD } 12.5 \mu \mathrm{g} / \mathrm{L} \\
(5.72,19.3)\end{array}$ \\
\hline $\begin{array}{l}\text { Polycythemia } \\
\text { (haematocrit }>65 \% \text {; } \\
\text { only term neonates) }\end{array}$ & 3 & RCTs & $\begin{array}{l}\text { No major } \\
\text { limitations }\end{array}$ & $\begin{array}{l}\text { Effect not } \\
\text { significant, } \\
\text { with wide CI }\end{array}$ & $\begin{array}{l}\text { All } 3 \text { studies } \\
\text { indicate no } \\
\text { effect, but ES of } \\
2 \text { indicate } \\
\text { substantial } \\
\text { increase }\end{array}$ & $\begin{array}{l}\text { From low- and } \\
\text { middle- } \\
\text { income } \\
\text { country } \\
\text { settings }\end{array}$ & LOW & $\begin{array}{l}\text { RR 2.39 } \\
(0.72,7.93)\end{array}$ \\
\hline $\begin{array}{l}\text { Hyperbilirubin- } \\
\text { aemia receiving } \\
\text { phototherapy } \\
\text { (in both term and } \\
\text { preterm infants) }\end{array}$ & 7 & RCTs & $\begin{array}{l}\text { Limitations in } \\
\text { measurement, } \\
\text { follow-up and } \\
\text { analysis }\end{array}$ & $\begin{array}{l}\text { Pooled effect } \\
\text { significant, } \\
\text { lower limit of } \\
\text { CI close to } \\
\text { null }\end{array}$ & $\begin{array}{l}\text { ES of studies } \\
\text { with }>75 \% \text { of } \\
\text { total weight in } \\
\text { the same } \\
\text { direction as } \\
\text { pooled effect }\end{array}$ & $\begin{array}{l}\text { Most of the } \\
\text { evidence from } \\
\text { high-income } \\
\text { country } \\
\text { settings; } \\
\text { outcome not } \\
\text { based on } \\
\text { objective } \\
\text { criteria }\end{array}$ & VERY LOW & $\begin{array}{l}\text { RR 1.33 } \\
(1.07,1.66)\end{array}$ \\
\hline
\end{tabular}




\section{Recommendation 2: Additional stimulation (beyond drying) after birth}

GRADE tables were not generated as none of the studies have compared the effect of 'additional stimulation' with 'no additional stimulation' at the time of birth.

\section{Recommendation 3: Oral/nasal suctioning in infants born through clear amniotic \\ fluid}

\begin{tabular}{|c|c|c|c|c|c|c|c|c|}
\hline Outcome & $\begin{array}{l}\text { No. of } \\
\text { studies }\end{array}$ & Design & $\begin{array}{l}\text { Limitations } \\
\text { in methods }\end{array}$ & Precision & Consistency & $\begin{array}{l}\text { General- } \\
\text { izability / } \\
\text { directness }\end{array}$ & $\begin{array}{l}\text { Overall } \\
\text { quality of } \\
\text { evidence }\end{array}$ & $\begin{array}{l}\text { Pooled ES (95\% } \\
\text { CI) }\end{array}$ \\
\hline $\begin{array}{l}\text { Oxygen } \\
\text { saturation levels } \\
\text { (at } 5 \text { minutes of } \\
\text { life) }\end{array}$ & 3 & RCTs & $\begin{array}{l}\text { No serious } \\
\text { limitations }\end{array}$ & $\begin{array}{l}\text { Pooled effect } \\
\text { significant, } \\
\text { upper limit of } \\
\text { CI indicates } \\
\text { meaningful } \\
\text { effect }\end{array}$ & $\begin{array}{l}\text { Three studies, } \\
\text { ES in same } \\
\text { direction }\end{array}$ & $\begin{array}{l}\text { From low- } \\
\text { and middle- } \\
\text { income } \\
\text { country } \\
\text { settings }\end{array}$ & HIGH & $\begin{array}{l}\text { MD } \\
-9.8 \% \\
(-10.2 \%,-9.4 \%)\end{array}$ \\
\hline $\begin{array}{l}\text { Normal Apgar } \\
\text { scores } \\
\text { ( } \geq 9 \text { at } 5 \text { minutes } \\
\text { after birth) }\end{array}$ & 3 & RCTs & $\begin{array}{l}\text { Limitations in } \\
\text { measurement }\end{array}$ & $\begin{array}{l}\text { Pooled effect } \\
\text { not } \\
\text { significant , } \\
\text { with wide CI }\end{array}$ & $\begin{array}{l}\text { ES of studies } \\
\text { with }<75 \% \\
\text { weight } \\
\text { consistent with } \\
\text { no effect }\end{array}$ & $\begin{array}{l}\text { Majority of } \\
\text { evidence from } \\
\text { studies in } \\
\text { developing } \\
\text { countries }\end{array}$ & LOW & $\begin{array}{l}\text { RR } 0.54 \\
(0.28 \text { to } 1.07)\end{array}$ \\
\hline
\end{tabular}




\section{Recommendation 4: Intrapartum suctioning in infants born through meconium}

\begin{tabular}{|c|c|c|c|c|c|c|c|c|}
\hline Outcome & $\begin{array}{l}\text { No. of } \\
\text { studies }\end{array}$ & Design & $\begin{array}{l}\text { Limitations } \\
\text { in methods }\end{array}$ & Precision & Consistency & $\begin{array}{l}\text { General- } \\
\text { izability / } \\
\text { directness }\end{array}$ & $\begin{array}{l}\text { Overall } \\
\text { quality of } \\
\text { evidence }\end{array}$ & $\begin{array}{l}\text { Pooled ES } \\
(95 \% \mathrm{CI})\end{array}$ \\
\hline $\begin{array}{l}\text { Mortality } \\
\text { (during initial } \\
\text { hospital stay) }\end{array}$ & 1 & RCT & $\begin{array}{l}\text { No serious } \\
\text { limitations }\end{array}$ & $\begin{array}{l}\text { Effect not } \\
\text { significant, } \\
\text { with wide CI }\end{array}$ & Single study & $\begin{array}{l}\text { Study from } \\
\text { low- or } \\
\text { middle- } \\
\text { income } \\
\text { country } \\
\text { setting }\end{array}$ & LOW & $\begin{array}{l}\text { RR } 2.22 \\
\text { (0.69 to } 7.22)\end{array}$ \\
\hline $\begin{array}{l}\text { Meconium } \\
\text { aspiration } \\
\text { syndrome }\end{array}$ & 4 & $\begin{array}{l}\text { Majority of } \\
\text { evidence } \\
\text { from RCT }\end{array}$ & $\begin{array}{l}\text { No serious } \\
\text { limitations }\end{array}$ & $\begin{array}{l}\text { Pooled effect } \\
\text { not } \\
\text { significant, } \\
\text { with wide CI }\end{array}$ & $\begin{array}{l}\text { Pooled ES } \\
\text { indicates no } \\
\text { effect, ES of } \\
\text { studies with } \\
<75 \% \text { weight } \\
\text { consistent with } \\
\text { no effect }\end{array}$ & $\begin{array}{l}\text { Majority of } \\
\text { evidence from } \\
\text { study in low- } \\
\text { or middle- } \\
\text { income } \\
\text { country } \\
\text { setting }\end{array}$ & LOW & $\begin{array}{l}\text { RR 1.07 } \\
(0.80,1.44)\end{array}$ \\
\hline $\begin{array}{l}\text { Apgar scores of } \\
\mathbf{6} \text { or less } \\
\text { (at } 5 \text { minutes } \\
\text { after birth) }\end{array}$ & 2 & $\begin{array}{l}\text { Majority of } \\
\text { evidence } \\
\text { from RCT }\end{array}$ & $\begin{array}{l}\text { Limitations in } \\
\text { measurement }\end{array}$ & $\begin{array}{l}\text { Pooled effect } \\
\text { not } \\
\text { significant, } \\
\text { with wide CI }\end{array}$ & $\begin{array}{l}\text { Only two } \\
\text { studies, ES of } \\
\text { both in same } \\
\text { direction }\end{array}$ & $\begin{array}{l}\text { Majority of } \\
\text { evidence from } \\
\text { study in low- } \\
\text { or middle- } \\
\text { income } \\
\text { country } \\
\text { setting }\end{array}$ & LOW & $\begin{array}{l}\text { RR 0.88 } \\
(0.63,1.23)\end{array}$ \\
\hline $\begin{array}{l}\text { Air leaks - } \\
\text { pneumothorax/ } \\
\text { pulmonary } \\
\text { interstitial } \\
\text { emphysema }\end{array}$ & 1 & RCT & $\begin{array}{l}\text { No serious } \\
\text { limitations }\end{array}$ & $\begin{array}{l}\text { Effect not } \\
\text { significant, } \\
\text { with wide CI }\end{array}$ & Single study & $\begin{array}{l}\text { Study from } \\
\text { low- or } \\
\text { middle- } \\
\text { income } \\
\text { country } \\
\text { setting }\end{array}$ & LOW & $\begin{array}{l}\text { RR } 2.22 \\
\text { (0.69 to } 7.22 \text { ) }\end{array}$ \\
\hline $\begin{array}{l}\text { Duration of } \\
\text { hospital stay }\end{array}$ & 1 & RCT & $\begin{array}{l}\text { No serious } \\
\text { limitations }\end{array}$ & $\begin{array}{l}\text { Effect not } \\
\text { significant , } \\
\text { with wide CI }\end{array}$ & Single study & $\begin{array}{l}\text { Study from } \\
\text { low- or } \\
\text { middle- } \\
\text { income } \\
\text { country } \\
\text { setting }\end{array}$ & LOW & $\begin{array}{l}\text { MD } \\
-0.8 \text { days } \\
(-4.8 \text { to } 3.2)\end{array}$ \\
\hline
\end{tabular}




\section{Recommendation 5: Oropharyngeal and/or tracheal suctioning in infants born through meconium*}

\begin{tabular}{|c|c|c|c|c|c|c|c|c|}
\hline Outcome & $\begin{array}{l}\text { No. of } \\
\text { studies }\end{array}$ & Design & $\begin{array}{l}\text { Limitations } \\
\text { in methods }\end{array}$ & Precision & Consistency & $\begin{array}{l}\text { General- } \\
\text { izability / } \\
\text { directness }\end{array}$ & $\begin{array}{l}\text { Overall } \\
\text { quality of } \\
\text { evidence }\end{array}$ & $\begin{array}{l}\text { Pooled ES } \\
(95 \% \mathrm{CI})\end{array}$ \\
\hline $\begin{array}{l}\text { Mortality } \\
\text { (during initial } \\
\text { hospital stay) }\end{array}$ & 2 & RCTs & $\begin{array}{l}\text { No serious } \\
\text { limitations }\end{array}$ & $\begin{array}{l}\text { Pooled effect } \\
\text { not } \\
\text { significant, } \\
\text { with wide CI }\end{array}$ & $\begin{array}{l}\text { Two studies } \\
\text { with effects in } \\
\text { different } \\
\text { directions }\end{array}$ & $\begin{array}{l}\text { Both from } \\
\text { low- and } \\
\text { middle- } \\
\text { income } \\
\text { country } \\
\text { settings }\end{array}$ & LOW & $\begin{array}{l}\text { RR } 0.96 \\
(0.22 \text { to } 4.25 \text { ) }\end{array}$ \\
\hline $\begin{array}{l}\text { Meconium } \\
\text { aspiration } \\
\text { syndrome }\end{array}$ & 2 & RCTs & $\begin{array}{l}\text { No serious } \\
\text { limitations }\end{array}$ & $\begin{array}{l}\text { Pooled effect } \\
\text { not } \\
\text { significant, } \\
\text { with wide CI }\end{array}$ & $\begin{array}{l}\text { Two studies; } \\
\text { effects of both } \\
\text { in same } \\
\text { direction as } \\
\text { pooled effect }\end{array}$ & $\begin{array}{l}\text { Majority of } \\
\text { evidence from } \\
\text { study in low- } \\
\text { or middle- } \\
\text { income } \\
\text { country } \\
\text { setting }\end{array}$ & MODERATE & $\begin{array}{l}\text { RR 1.33 } \\
(0.82,2.14)\end{array}$ \\
\hline $\begin{array}{l}\text { Air leaks } \\
\text { (during initial } \\
\text { hospital stay) }\end{array}$ & 2 & RCTs & $\begin{array}{l}\text { Limitations in } \\
\text { allocation and } \\
\text { measurement }\end{array}$ & $\begin{array}{l}\text { Effect not } \\
\text { significant, } \\
\text { with wide CI }\end{array}$ & $\begin{array}{l}\text { Two studies } \\
\text { with effects in } \\
\text { different } \\
\text { directions }\end{array}$ & $\begin{array}{l}\text { Majority of } \\
\text { evidence from } \\
\text { study in low- } \\
\text { or middle- } \\
\text { income } \\
\text { country } \\
\text { setting }\end{array}$ & VERY LOW & $\begin{array}{l}\text { RR } 0.87 \\
(0.16 \text { to } 4.92 \text { ) }\end{array}$ \\
\hline $\begin{array}{l}\text { Hypoxic- } \\
\text { ischemic } \\
\text { encephalo- } \\
\text { pathy and/or } \\
\text { convulsions } \\
\text { (immediate } \\
\text { neonatal } \\
\text { period) }\end{array}$ & 1 & RCT & $\begin{array}{l}\text { Limitations in } \\
\text { follow-up and } \\
\text { analysis }\end{array}$ & $\begin{array}{l}\text { Effect not } \\
\text { significant, } \\
\text { with wide CI }\end{array}$ & Single study & $\begin{array}{l}\text { Study from } \\
\text { low- or } \\
\text { middle- } \\
\text { income } \\
\text { country } \\
\text { setting }\end{array}$ & VERY LOW & $\begin{array}{l}\text { RR } 2.65 \\
\text { (0.30 to 23.8) }\end{array}$ \\
\hline
\end{tabular}

*GRADE profile summary of the effect of tracheal suctioning in neonates who start breathing on their own; no GRADE tables were generated for the effect of tracheal suctioning in infants who do not start breathing on their own (all were observational studies).

Recommendation 6: Optimal suctioning device(s) for oropharyngeal suctioning

GRADE tables were not generated as there were no relevant comparative human studies.

\section{Recommendation 7: Timing of positive-pressure ventilation}

GRADE tables were not generated as only one very low quality observational study was identified. 
Recommendation 8: Air versus oxygen during positive-pressure ventilation

\begin{tabular}{|c|c|c|c|c|c|c|c|c|}
\hline Outcome & $\begin{array}{l}\text { No. of } \\
\text { studies }\end{array}$ & Design & $\begin{array}{l}\text { Limitations } \\
\text { in methods }\end{array}$ & Precision & Consistency & $\begin{array}{l}\text { General- } \\
\text { izability / } \\
\text { directness }\end{array}$ & $\begin{array}{l}\text { Overall } \\
\text { quality of } \\
\text { evidence }\end{array}$ & $\begin{array}{l}\text { Pooled ES } \\
(95 \% \mathrm{CI})\end{array}$ \\
\hline $\begin{array}{l}\text { Mortality } \\
\text { (in the first week } \\
\text { in } 4 \text { studies, } \\
\text { during neonatal } \\
\text { period in } 2 \text {, and } \\
\text { until discharge in } \\
1 \text { study) }\end{array}$ & 7 & $\begin{array}{l}\text { Majority of } \\
\text { evidence } \\
\text { from } \\
\text { quasi- } \\
\text { RCTs }\end{array}$ & $\begin{array}{l}\text { No major } \\
\text { limitations }\end{array}$ & $\begin{array}{l}\text { Pooled effect } \\
\text { significant, } \\
\text { but upper } \\
\text { limit of CI } \\
\text { close to null }\end{array}$ & $\begin{array}{l}\text { ES of studies } \\
\text { with }>75 \% \text { of } \\
\text { total evidence } \\
\text { in the same } \\
\text { direction as } \\
\text { pooled effect }\end{array}$ & $\begin{array}{l}\text { Majority of } \\
\text { evidence from } \\
\text { studies in } \\
\text { low- and } \\
\text { middle- } \\
\text { income } \\
\text { country } \\
\text { settings }\end{array}$ & MODERATE & $\begin{array}{l}\text { OR } 0.70 \\
\text { (0.51 to } 0.97 \text { ) }\end{array}$ \\
\hline $\begin{array}{l}\text { Hypoxic- } \\
\text { ischemic } \\
\text { encephalo- } \\
\text { pathy - stage } 2 \\
\text { or } 3\end{array}$ & 4 & $\begin{array}{l}\text { Quasi- } \\
\text { RCTs }\end{array}$ & $\begin{array}{l}\text { Limitations in } \\
\text { measurement }\end{array}$ & $\begin{array}{l}\text { Pooled effect } \\
\text { not } \\
\text { significant, } \\
\text { with wide CI }\end{array}$ & $\begin{array}{l}\text { All } 4 \text { studies } \\
\text { indicate no } \\
\text { effect }\end{array}$ & $\begin{array}{l}\text { From low- } \\
\text { and middle- } \\
\text { income } \\
\text { country } \\
\text { settings }\end{array}$ & LOW & $\begin{array}{l}\text { OR } 0.89 \\
(0.66,1.19)\end{array}$ \\
\hline $\begin{array}{l}\text { Onset of } \\
\text { spontaneous } \\
\text { respiration } \\
\text { (in the neonatal } \\
\text { period) }\end{array}$ & 1 & RCT & $\begin{array}{l}\text { Limitations in } \\
\text { follow-up and } \\
\text { analysis }\end{array}$ & $\begin{array}{l}\text { Effect } \\
\text { significant, } \\
\text { upper limit of } \\
\text { CI meaningful }\end{array}$ & Single study & $\begin{array}{l}\text { From high- } \\
\text { income } \\
\text { country } \\
\text { setting }\end{array}$ & LOW & $\begin{array}{l}\text { MD } \\
-1.50 \text { minutes } \\
(-2.02,-0.98)\end{array}$ \\
\hline 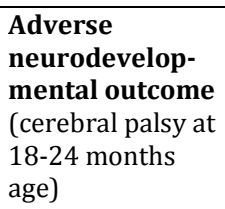 & 1 & Quasi-RCT & $\begin{array}{l}\text { Limitations in } \\
\text { measurement } \\
\text { and follow-up }\end{array}$ & $\begin{array}{l}\text { Effect not } \\
\text { significant, } \\
\text { with wide CI }\end{array}$ & Single study & $\begin{array}{l}\text { From low- or } \\
\text { middle- } \\
\text { income } \\
\text { country } \\
\text { setting }\end{array}$ & VERY LOW & $\begin{array}{l}\text { OR } 1.38 \\
(0.46,4.10)\end{array}$ \\
\hline
\end{tabular}


Recommendation 9: Optimal method of providing positive-pressure ventilation

\begin{tabular}{|c|c|c|c|c|c|c|c|c|}
\hline Outcome & $\begin{array}{l}\text { No. of } \\
\text { studies }\end{array}$ & Design & $\begin{array}{l}\text { Limitations } \\
\text { in methods }\end{array}$ & Precision & Consistency & $\begin{array}{l}\text { General- } \\
\text { izability / } \\
\text { directness }\end{array}$ & $\begin{array}{l}\text { Overall } \\
\text { quality of } \\
\text { evidence }\end{array}$ & $\begin{array}{l}\text { Pooled ES } \\
(95 \% \mathrm{CI})\end{array}$ \\
\hline $\begin{array}{l}\text { Mortality } \\
\text { (during neonatal } \\
\text { period in both the } \\
\text { studies) }\end{array}$ & 2 & $\begin{array}{l}\text { One quasi- } \\
\text { RCT and } \\
\text { one } \\
\text { observa- } \\
\text { tional } \\
\text { study }\end{array}$ & $\begin{array}{l}\text { No serious } \\
\text { limitations }\end{array}$ & $\begin{array}{l}\text { Effect not } \\
\text { significant, } \\
\text { with wide CI }\end{array}$ & $\begin{array}{l}\text { Two studies } \\
\text { with effect in } \\
\text { different } \\
\text { directions }\end{array}$ & $\begin{array}{l}\text { Both studies } \\
\text { from low- or } \\
\text { middle- } \\
\text { income } \\
\text { country } \\
\text { settings }\end{array}$ & VERY LOW & $\begin{array}{l}\text { RR } 1.01 \\
\text { (0.39 to } 2.60 \text { ) }\end{array}$ \\
\hline $\begin{array}{l}\text { First cry within } \\
5 \text { minutes after } \\
\text { birth }\end{array}$ & 1 & Quasi-RCT & $\begin{array}{l}\text { Limitations in } \\
\text { measurement }\end{array}$ & $\begin{array}{l}\text { Effect not } \\
\text { significant, } \\
\text { with wide CI }\end{array}$ & Single study & $\begin{array}{l}\text { From low-or } \\
\text { middle- } \\
\text { income } \\
\text { country } \\
\text { setting }\end{array}$ & VERY LOW & $\begin{array}{l}\text { RR 1.27 } \\
(0.93,1.73)\end{array}$ \\
\hline $\begin{array}{l}\text { Apgar score } \geq \mathbf{4} \\
\text { (at } 5 \text { minutes } \\
\text { after birth) }\end{array}$ & 1 & Quasi-RCT & $\begin{array}{l}\text { Limitations in } \\
\text { measurement }\end{array}$ & $\begin{array}{l}\text { Effect not } \\
\text { significant, } \\
\text { with wide CI }\end{array}$ & Single study & $\begin{array}{l}\text { From low-or } \\
\text { middle- } \\
\text { income } \\
\text { country } \\
\text { setting }\end{array}$ & VERY LOW & $\begin{array}{l}\text { RR 0.99 } \\
(0.86,1.14)\end{array}$ \\
\hline $\begin{array}{l}\text { Convulsions } \\
\text { (in the neonatal } \\
\text { period) }\end{array}$ & 1 & Quasi-RCT & $\begin{array}{l}\text { Limitations in } \\
\text { measurement }\end{array}$ & $\begin{array}{l}\text { Effect not } \\
\text { significant, } \\
\text { with wide CI }\end{array}$ & Single study & $\begin{array}{l}\text { From low- or } \\
\text { middle- } \\
\text { income } \\
\text { country } \\
\text { setting }\end{array}$ & VERY LOW & $\begin{array}{l}\text { RR 0.92 } \\
(0.52,1.64)\end{array}$ \\
\hline
\end{tabular}

\section{Recommendation 10: Optimal interface for providing positive-pressure ventilation}

\begin{tabular}{|c|c|c|c|c|c|c|c|c|}
\hline Outcome & $\begin{array}{l}\text { No. of } \\
\text { studies }\end{array}$ & Design & $\begin{array}{l}\text { Limitations in } \\
\text { methods }\end{array}$ & Precision & Consistency & $\begin{array}{l}\text { General- } \\
\text { izability / } \\
\text { directness }\end{array}$ & $\begin{array}{l}\text { Overall } \\
\text { quality of } \\
\text { evidence }\end{array}$ & $\begin{array}{l}\text { Pooled ES } \\
(95 \% \text { CI })\end{array}$ \\
\hline Mortality & 1 & Quasi-RCT & $\begin{array}{l}\text { No serious } \\
\text { limitations }\end{array}$ & $\begin{array}{l}\text { Effect not } \\
\text { significant, } \\
\text { with wide CI }\end{array}$ & Single study & $\begin{array}{l}\text { From high- } \\
\text { income } \\
\text { country setting }\end{array}$ & VERY LOW & $\begin{array}{l}\text { RR } 0.49 \\
(0.21,1.11)\end{array}$ \\
\hline $\begin{array}{l}\text { Need for chest } \\
\text { com-pressions }\end{array}$ & 1 & Quasi-RCT & $\begin{array}{l}\text { Limitations in } \\
\text { measurement }\end{array}$ & $\begin{array}{l}\text { Effect } \\
\text { significant; } \\
\text { lower limit } \\
\text { of CI } \\
\text { meaningful }\end{array}$ & Single study & $\begin{array}{l}\text { From high- } \\
\text { income } \\
\text { country setting }\end{array}$ & LOW & $\begin{array}{l}\text { RR } 0.2 \\
(0.08 \text { to } \\
0.51)\end{array}$ \\
\hline $\begin{array}{l}\text { Pulmonary air } \\
\text { leaks } \\
\text { (in the first } 72 \\
\text { hours of life) }\end{array}$ & 1 & Quasi-RCT & $\begin{array}{l}\text { Limitations in } \\
\text { measurement }\end{array}$ & $\begin{array}{l}\text { Effect not } \\
\text { significant, } \\
\text { with wide CI }\end{array}$ & Single study & $\begin{array}{l}\text { From high- } \\
\text { income } \\
\text { country setting }\end{array}$ & VERY LOW & $\begin{array}{l}\text { RR } 0.66 \\
(0.26,1.68)\end{array}$ \\
\hline
\end{tabular}


Recommendation 11: Assessing the response to positive-pressure ventilation

GRADE tables were not generated as none of the studies compared the effect of measuring heart rate and chest movements with assessment of chest movements alone after initiation of PPV.

Recommendation 12: Need for providing chest compressions along with positivepressure ventilation

GRADE tables were not generated as there were no relevant comparative human studies.

\section{Recommendation 13: Stopping resuscitation}

GRADE tables were not generated as none of the studies compared the effect of cessation of resuscitation efforts at 10 minutes versus at 20 minutes after birth or later. 


\section{ANNEX 2: LIST OF EXTERNAL PARTICIPANTS}

\section{GUIDELINES DEVELOPMENT GROUP MEMBERS}

\section{Dr Jose Luis DÍAZ-ROSSELLO}

Perinatal Pediatrics

Latin American Centre for Perinatology, Women Maternal and Reproductive Health Unit (CLAP/WMR)

Regional Office for the Americas

World Health Organization

Montevideo, Uruguay

Dr Peter GISORE

Neonatal Specialist

Moi University School of Medicine

Eldoret, Kenya

\section{Dr SUSAn NIERMEYER}

Professor of Pediatrics

University of Colorado School of Medicine

Aurora, Colorado, USA

\section{Professor Vinod K PAUL}

Head of Department of Paediatrics

All India Institute of Medical Sciences

New Delhi, India

\section{Ms Ana QUIROGA}

Neonatal nurse

Ministry of Health

Buenos Aires, Argentina

\section{Professor Ola Didrik SAUGSTAD}

Director

Department of Pediatric Research

Rikshospitalet Medical Centre

University of Oslo

Oslo, Norway

\section{Dr Maria Asunción SILVESTRE}

Associate Professor of Pediatrics and Newborn Medicine

University of the Philippines College of Medicine

New Manila, Philippines

Dr Nalini SINGHAL

Professor of Pediatrics

University of Calgary

Calgary, Alberta, Canada 


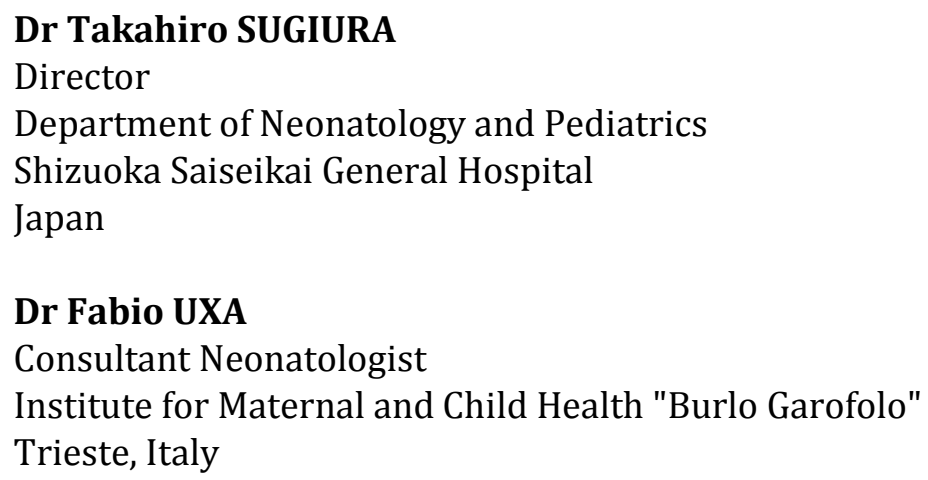

\section{CONTRIBUTED TO DEVELOPMENT OF QUESTIONS AND/OR PEER REVIEW}

Dr Uwe EWALD

Department of Women's and Children's Health

Uppsala University

Uppsala, Sweden

\section{Dr Pavitra MOHAN}

Health Specialist

UNICEF India Country Office

New Delhi, India

\section{Ms Yana RICHENS}

Consultant Midwife

University College Hospital

London, United Kingdom

\section{Professor Frederik WERE}

University of Nairobi

Nairobi, Kenya

Professor David WOODS

Perinatal Education Trust

Cape Town, South Africa

\section{OBSERVERS}

Dr Pablo DURAN

Medical Officer

CLAP/SMR

Region of the Americas, World Health Organization 


\section{Dr Vincent FAVEAU}

Senior Maternal Health Advisor

UNFPA

Switzerland

\section{Ms Patricia P GOMEZ}

Clinical Specialist, ACCESS Program

Jhpiego-an affiliate of Johns Hopkins University

Baltimore, Maryland, USA

\section{Dr Lily KAK}

Senior Maternal and Newborn Health Advisor

United States Agency for International Development

USA

Dr William KEENAN

Executive Director

International Pediatric Association

Professor of Pediatrics and Obstetrics

Saint Louis University

St Louis, Missouri, USA

\section{Dr Yaron WOLMAN}

Maternal Health Technical Officer

UNFPA

Switzerland 
For further information please contact:

World Health Organization

Department of Maternal, Newborn, Child and Adolescent Health (MCA)

20 Avenue Appia, 1211 Geneva 27, Switzerland

Tel +41227913281

Fax +41227914853

E-mail: mca@who.int

Web site : http://www.who.int/maternal_child_adolescent/en/

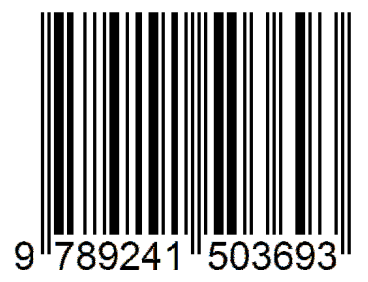

